\title{
SKELETONS IN THE DATABASE: AN EARLY ANALYSIS OF THE CFPB'S CONSUMER COMPLAINTS
}

\author{
Ian Ayres, Jeff Lingwall \& Sonia Steinway*
}

\begin{abstract}
Analyzing a new dataset of 110,000 consumer complaints lodged with the Consumer Financial Protection Bureau (the "CFPB" or the "Bureau"), the authors find that: (i) Bank of America, Citibank, and PNC Bank were significantly less timely in responding to consumer complaints than the average financial institution; (ii) consumers of some of the largest financial services providers, including Wells Fargo, American Express ("Amex"), and Bank of America, were significantly more likely than the average consumer to dispute the provider's response to their initial complaints; and (iii) among the companies included in the database that provide mortgages, OneWest Bank, HSBC, Nationstar Mortgage, and Bank of America all received more mortgage complaints relative to mortgages sold than other mortgage providers. In addition, regression analysis suggests that consumer financial companies respond differently to complaints, depending on the type of product and issues involved, thereby generating significant differences in the timeliness of responses and whether consumers dispute those responses. Moreover, demographics matter: mortgage complaints per mortgage significantly increased in ZIP codes with larger proportions of certain populations, including Blacks and Hispanics. Companies were also less timely, and more likely to have their responses disputed, in areas with higher concentrations of senior citizens and college students, groups on which the CFPB is mandated to focus.
\end{abstract}

* Participants in Yale Law School's Empirical Law and Economics seminar and Nancy Welsh provided helpful comments. Ian Ayres has served as an economic expert for proposed plaintiff classes in several cases relating in part to alleged untimely decisionmaking regarding permanent mortgage modifications under the Home Affordable Mortgage Program. 


\section{TABLE OF CONTENTS}

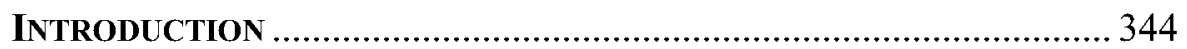

I. The Consumer Financial Protection Bureau ........................ 347

II. THE CFPB's CoMPLAINTS Process ............................................ 350

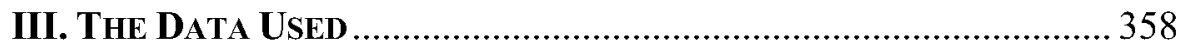

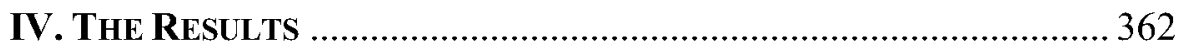

A. THE COMPANY-SPECIFIC RESULTS .......................................... 362

B. Results Based on ZIP Code Demographics, Products, AND SPECIFIC ISSUES............................................................. 363

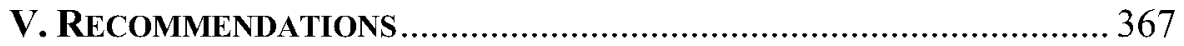

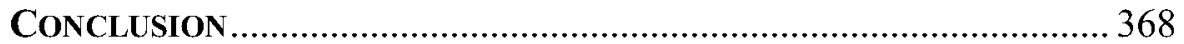

APPENDIX: VARIABLES INCLUDED IN THE ANALYSIS..............................370

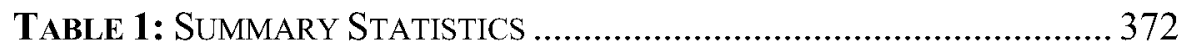

TABLE 2: PRODUCT TYPES AND ISSUES ................................................ 373

TABLE 3: COMPANY-SPECIFIC PROPORTION OF COMPLAINTS WITH

UNTIMELY COMPANY RESPONSES ...................................................... 376

TABLE 4: COMPANY-SPECIFIC PROPORTION OF COMPANY

RESPONSES DISPUTED BY CONSUMER ………………..................... 378

TABle 5: MORTGage COMPLAInTS PER Mortgage Originated, LARGEST BANKS

TABLE 6: REGRESSIONS OF LOG OF MORTGAGE COMPLAINTS PER

MORTGage Originated ON DEMOGRAPHIC FACTORS OF ZIP

CODE

TABLE 7: LOGIT REGRESSIONS OF UNTIMELY RESPONSES ON ZIP

CODE DEMOGRAPHIC FACTORS ........................................................ 382

TABLE 8: LOGIT REGRESSIONS OF DISPUTED RESPONSES ON ZIP

CODE DEMOGRAPHIC FACTORS

TABLE 9: Product By ISSUE INTERACTIONS From TABLE 7: THE

Five Product Issues Most AND Least Likely to BE

UNTIMELY 388

TABLE 10: Product By ISSUE INTERACTIONS FROM TABLE 8: THE

Five Product IsSUES MOST AND LEAST LIKELY TO BE

DISPUTED 390

\section{INTRODUCTION}

Since its inception in 2011, the CFPB has enabled consumers to submit complaints about "unfair, deceptive, or abusive acts or practices" 
by financial services companies. The purpose of this complaint process, required under the Dodd-Frank Wall Street Reform and Consumer Protection Act ${ }^{1}$ ("Dodd-Frank") is threefold: (1) to assist individual consumers with specific complaints; (2) to focus the Bureau's enforcement and regulatory efforts on specific companies and general "business practices that may pose risks to consumers" based on aggregate consumer concerns; and (3) by making the data publicly available, to provide the financial services industry with a high-level view of what matters to consumers and to provide consumers with a view into how companies are meeting those needs. ${ }^{2}$ The raw complaint data is updated nightly and available to download from the Bureau's website. ${ }^{3}$ Although the CFPB analyzes some of the data internally for its semiannual reports to Congress, the Bureau encourages "the public, including consumers, the companies that serve them, analysts, data scientists, civic hackers, developers, policymakers, journalists, and academics, to analyze, augment, and build on the public database" as well. ${ }^{4}$

The analysis that follows is in keeping with that request. The authors of this Article have assessed the approximately 110,000 complaints included in the CFPB's Consumer Complaint Database (the "Database") as of June 3, 2013. The results indicate that in the aggregate, these complaints provide a veritable treasure trove of data for assessing the work of the Bureau and the companies under its watch.

The authors analyzed the complaints in three key ways. First, they looked at the data by company to analyze differences in performance on the percentage of company responses disputed by customers, the percentage of company responses that the CFPB did not receive in a timely manner, and for mortgages specifically, the number of complaints relative to products sold. The authors found that Bank of America, Citibank, and PNC Bank were all significantly less timely in

1. Dodd-Frank Wall Street Reform and Consumer Protection Act, Pub. L. No. 111-203, 124 Stat. 1376 (2010) (codified in scattered sections of 12 U.S.C.).

2. See Submit a Complaint, Consumer Fin. Protection Bureau, http://www.consumerfinance.gov/complaint/.

3. See Consumer Complaint Database, Consumer Fin. Protection Bureau, http:/www.consumerfinance.gov/complaintdatabase/.

4. Richard Cordray, Director of the Consumer Fin. Prot. Bureau, Remarks at the Consumer Response Field Hearing (Mar. 28, 2013), available at http://www.consumerfinance.gov/speeches/prepared-remarks-of-director-richardcordray-at-the-consumer-response-field-hearing/ [hereinafter Cordray, Field Hearing Prepared Remarks]. 
responding to complaints than the average financial institution. Additionally, consumers of some of the largest financial services providers, including Wells Fargo, Amex, and Bank of America, were significantly more likely than the average consumer to dispute the company's response. Among companies that provide mortgages, OneWest Bank, HSBC, Nationstar Mortgage, and Bank of America all generated more mortgage complaints relative to mortgages sold than other banks. These results should be of interest to both the CFPB and the companies named above.

Second, the authors' analysis examined differences between products and the specific issues about which consumers complained. Financial institutions were significantly less timely in responding to complaints concerning identity theft, fraud, or embezzlement, compared to credit card interest rate complaints (the credit card issue with the most complaints), while bank account and credit card complaints were more likely to receive a timely response relative to mortgage complaints (the product category with the most complaints). Similarly, bank account, credit card, and student loan consumers were less likely to dispute the company's response to their complaints, compared to mortgage complaints. However, those who complained specifically about bankruptcy issues related to credit cards, credit card cash advances, collection of debt disputes, and credit reporting (either to a credit card company or credit reporting agency) were significantly more likely to dispute the company's response, relative to other issues concerning the same products.

Third, the authors of this Article also regressed the complaint data on a number of regional demographic factors by ZIP code or ZIP Code Tabulation Area ("ZCTA") in order to assess the likelihood of certain populations availing themselves of the CFPB's complaints process in the first place. Once the consumer made a complaint, the authors also assessed how likely companies were to respond in a timely fashion and how likely those consumers were to dispute the response. Across a variety of specifications (controlling for time, company, product, issue,

5. ZIP Code Tabulation Areas (ZCTAs) are generalized areal representations of U.S. Postal Service ZIP Code service areas. ZIP codes, by contrast, are a collection of mail delivery routes. In most instances, ZIP codes and ZCTAs are identical, although that is not always the case. See generally ZIP Code Tabulation Areas (ZCTAs), U.S. CENSus BuREAU, http://www.census.gov/geo/reference/zctas.html (last revised June 20, 2013). 
and state fixed effects), the authors found statistically significant increases in complaints per mortgage in ZIP codes with larger residential proportions of Black, Hispanic, senior citizens (those over 65 years of age), and high school and college graduates. In analogous regressions for the likelihood that company responses were untimely or disputed, a number of these demographic factors were likewise significant, including the proportion of senior citizens and the percentage of college enrollees. By virtue of the mandates built into Dodd-Frank, these subgroups are of particular interest to the Bureau, as discussed below.

Part I of this Article provides the general background of the CFPB. Part II describes the process by which consumers can lodge complaints with the CFPB and details the history and structure of the Consumer Complaint Database. Part III explains the empirical methodology and summary statistics for the complaints in the Database. Part IV presents the results of the analysis. Part V considers the implications of these findings for the CFPB and the financial services companies that it regulates.

\section{The Consumer Financial Protection Bureau}

Title X of Dodd-Frank established the CFPB as the independent executive agency responsible for regulating "the offering and provision of consumer financial products or services under the Federal consumer financial laws." The mission of the Bureau is to "make markets for consumer financial products and services work for Americans - whether they are applying for a mortgage, choosing among credit cards, or using any number of other consumer financial products." 7 The CFPB operates on a budget of $\$ 541$ million annually, about $10 \%$ of which is allocated to consumer response operations, e.g., the formal complaints process. ${ }^{8}$ In addition to assisting consumers with specific complaints and aggregating complaint data, the CFPB also works to educate consumers,

6. 12 U.S.C. $\S 5491$ (a) (2012). As a note, the agency is not "independent" in certain respects, i.e., it is housed for budgetary purposes in the Federal Reserve. See infra note 26 and accompanying text.

7. About Us, Consumer Fin. Protection Bureau (Dec. 10, 2013), http://www.consumerfinance.gov/the-bureau/ [hereinafter CFPB, About Us].

8. The CFPB Strategic Plan, Budget, and Performance Plan and Report, CONSUMER Fin. PROTECTION BurEau (Apr. 2013), http://www.consumerfinance.gov/ strategic-plan-budget-and-performance-plan-and-report/\#budget-overview [hereinafter CFPB, Strategic Plan]. 
research consumer behavior, supervise financial companies with over $\$ 10$ billion in assets, and enforce federal consumer financial protection laws. ${ }^{\text {? }}$

The concept of a federal consumer financial protection agency dates back to a 2007 essay by then-Harvard Law Professor Elizabeth Warren in the summer edition of the Democracy journal. ${ }^{10}$ Warren's "Unsafe at Any Rate" intentionally echoed Ralph Nader's 1965 "Unsafe at Any Speed," which detailed the dangers of an unregulated automotive industry. " She decried the "tattered patchwork" of oversight over financial products and services. ${ }^{12}$ In contrast to consumer products, which were subject to "basic safety regulations well in advance of reaching store shelves," Warren argued that overlapping state and federal regulatory regimes enabled financial services companies to "trick" and "trap" unwary consumers. ${ }^{13}$ Warren called for a Financial Product Safety Commission to be modeled after the U.S. Consumer Product Safety Commission of the 1970s with the mission "to establish guidelines for consumer disclosures, collect and report data about the uses of different financial products, review new financial products for safety, and require modification of dangerous products before they can be marketed to the public." 14

President Barak Obama, after his first presidential election, incorporated elements of Warren's plan into his economic agenda. ${ }^{15}$ In April of 2009, the White House's chief economic adviser, Lawrence Summers, met with his former Harvard colleague, Elizabeth Warren, apparently to discuss the design of a new regulatory agency. ${ }^{16}$ Around the same time, President Obama publicly supported the Consumer Financial Protection Agency Act of 2009, proposed as a stand-alone bill in April 2009 by Senators Dick Durbin (D-Ill.) and Charles Schumer (D-

9. See CFPB, About Us, supra note 7.

10. See Elizabeth Warren, Unsafe At Any Rate, DEMOCRACY, Summer 2007, at 8.

11. See RAlPh NADER, UNSAFE AT ANy SPEed (1965).

12. See Warren, supra note 10 , at 9 .

13. See id. at $9-11$.

14. See id. at 17.

15. Administration Said to Eye New Finance Regulatory Panel, N.Y. TIMES DEALBOOK (May 20, 2009), http://nyti.ms/1eFZKdh.

16. See Damian Paletta, Fight Over Consumer Agency Looms as Overhaul Is Signed, WaLL St. J., July 22, 2010, http://online.wsj.com/article/SB10001424052748 704746804575367502836650966.html. 
N.Y.) in the Senate ${ }^{17}$ and Representatives Brad Miller (D-Calif.) and Bill Delahunt (D-Mass.) in the House. ${ }^{18}$ President Obama used the same analogy in promoting the idea as Warren had in her 2007 article:

[w] hen you buy a toaster, if it explodes in your face, there's a law that says your toasters need to be safe. But when you get a credit card or a mortgage, there's no law on the books that says if that explodes in your face financially, somehow you're going to be protected. $^{19}$

In June of 2009, the Treasury Department under President Obama included a proposal for a new Consumer Financial Protection Agency (the "CFPA") in his comprehensive financial regulatory reform plan, "A New Foundation: Rebuilding Financial Supervision and Regulation." In keeping with Warren's original paper, the report argued that the CFPA was needed to "protect consumers and investors from financial abuse." 21 In particular, the goal of the agency was to "reduce gaps in federal supervision and enforcement; improve coordination with the states; set higher standards for financial intermediaries; and promote consistent regulation of similar products. ${ }^{, 22}$ Although financial industry executives heavily lobbied against the creation of a new regulatory body, the idea attracted legislative interest. ${ }^{23}$ Representative Barney Frank, an early supporter, helped shepherd the financial reform bill

17. Financial Product Safety Commission Act of 2009, S. 566, 111 th Cong. (2009).

18. Financial Product Safety Commission Act of 2009, H.R. 1705, 111th Cong. (2009). Representative Delahunt and Senator Durbin had previously sponsored the similar Consumer Credit Safety Commission Act of 2008 in the House and Senate, respectively; neither bill made it out of committee. See Adam J. Levitin, The Consumer Financial Protection Bureau: An Introduction, 32 REV. BANKING \& FIN. L. 321 (2013).

19. Ryan Grim, Obama Backs Financial Product Safety Commission Concept, HUFFINGTON POST, Apr. 20, 2009, www.huffingtonpost.com/2009/03/20/obama-backsfinancial-pro_n_177433.html.

20. See Dep't of the Treasury, A New Foundation: Rebuilding Financial SUPERVISION AND REGULATION, available at www.treasury.gov/initiatives/Documents/ FinalReport_web.pdf [hereinafter A NEW FOUNDATION].

21. See id. at 55 .

22. Id.

23. See, e.g., AMERICAN BANKers Association, THE CONSUMER FinanCial Protection Agency Act (H.R. 3126): The Wrong Approach to Stronger CONSUMER PROTECTION (July 2009), available at http:/www.aba.com/Press/ Documents/fc4d91913d034b199f17ecb7b6cc2c21ConsumerAgencyWrongApproachO nePager071709.pdf; Edmund L. Andrews, Banks Balk at Agency Meant to Aid Consumers, N.Y. TIMES, June 30, 2009, http://www.nytimes.com/2009/07/01/ business/economy/01regulate.html; Paletta, supra note 16. 
through the House with the agency provision intact, albeit with some modifications to garner Republican support and enable passage. ${ }^{24}$ In the Senate, Senator Christopher Dodd's financial reform plan also included provisions for the creation of a new agency. ${ }^{25}$ In contrast to the Obama and House plans, however, Senator Dodd's version was called the Consumer Financial Protection Bureau, and pursuant to a legislative compromise with Senator Bob Corker, Senator Dodd proposed that it be housed within the Federal Reserve. ${ }^{26}$ The final version of the bill retained both of these changes and was signed into law by President Obama on July $21,2010 .{ }^{27}$ The CFPB officially opened one year later on July 21,2011 with Richard Cordray as acting director. ${ }^{28}$

\section{The CFPB's Complaints Process}

The responsibility for receiving, settling, and aggregating individual consumer complaints seems to have been contemplated as part of the CFPB's ambit from the beginning. Although Professor Warren's 2007 article does not specifically advocate for a formal

24. House modifications from the original Obama proposal included: oversight by one director, rather than a four-member board; exemptions for community banks; and the loss of a planned requirement to have companies offer simpler ("plain vanilla") versions of particular products. See, e.g., David H. CARPENTER \& MARK Jickinng, CONG. RESEARCH SERV., R40696, FINANCIAL REgUlatory REForm: ANALYSIS OF THE Consumer financial Protection Agency (CFPA) as Proposed by the Obama ADMINISTRATION AND H.R. 3126 (2009), available at assets.opencrs.com/rpts/

R40696_20091109.pdf; Paletta, supra note 16; David Stout \& Stephen Labaton, Vote Backs a Financial Oversight Body, N.Y. TIMES, Oct. 22, 2009, www.nytimes.com $/ 2009 / 10 / 23 /$ business $/ 23$ regs.html?ref=consumerfinancialprotectionb ureau.

25. Arthur Delaney \& Shahien Nasiripour, Dodd Unveils Financial Regulatory Reform Bill With 'Consumer Financial Protection Bureau,' HufFIngton Post, June 17, 2010, www.huffingtonpost.com/2010/03/15/dodd-unveils-financial-re_n_499569.

26. Id.

27. Dodd-Frank Wall Street Reform and Consumer Protection Act, Pub. L. No. 111-203, 124 Stat. 1376 (2010) (codified in scattered sections of 12 U.S.C.).

28. The political battle over leadership of the agency is beyond the scope of this paper. See, e.g., Suzanna Andrews, The Woman Who Knew Too Much, VANITY FAIR, Nov. 2011, www.vanityfair.com/politics/features/2011/11/elizabeth-warren-201111. A letter dated May 2, 2011, signed by 44 Republican senators who refused to confirm any CFPB director without "reforms" in the Bureau's structure, is available online. Letter from Republican Senators, to Barrack Obama, President (May 2, 2011), available at www.aba.com/aba/documents/blogs/doddfrank/SenateToObamaCFPBApril2011.pdf. 
complaint process, maintaining a publicly available consumer product database that contains individual consumer complaints was an integral function of the Consumer Product Safety Commission that she used as her model. ${ }^{29}$ Every one of the pre-Dodd-Frank iterations of legislation to create a consumer financial agency had specifically vested it with the responsibility of receiving and resolving individual consumer complaints related to financial products and services. ${ }^{30}$ For example, one of the main objectives of the Commission created by the Consumer Credit Safety Commission Act of 2008 was to "collect, investigate, resolve, and inform the public about consumer complaints regarding consumer credit," including by creating a consumer credit customer hotline. ${ }^{31}$ Both the Senate and House versions of the Financial Product Safety Commission Act of 2009 used similar language to describe the complaints process to be included within the new agency's purview. ${ }^{32}$ Likewise, in explaining his 2009 "New Foundation" plan, President Obama claimed that to achieve its goals, the CFPA "should have a wide variety of tools" at its disposal, including authority for "collecting and tracking complaints about consumer financial services and facilitating complaint resolution with respect to federally-supervised institutions." ${ }^{33}$ Dodd-Frank preserves the consumer financial complaint process as one of the CFPB's core functions: ${ }^{34}$

The Director shall establish a unit whose functions shall include establishing a single, toll-free telephone number, a website, and a database or utilizing an existing database to facilitate the centralized collection of, monitoring of, and response to consumer complaints regarding consumer financial products or services. ${ }^{35}$

29. See Warren, supra note 10; see also Consumer Product Safety Act, 15 U.S.C. $\S \S 2051-2089$ (2012).

30. See, e.g., Consumer Credit Safety Commission Act, S. 3629, 110th Cong. (2008), available at http:/www.govtrack.us/congress/bills/110/s3629/text. The House version (H.R. 7258) was identical; see Consumer Credit Safety Commission Act, H.R. 7258, 110th Cong. (2008); see also supra notes 17 and 18.

31. See, e.g., Consumer Credit Safety Commission Act, S. 3629, 110th Cong. (2008), available at http://www.govtrack.us/congress/bills/110/s3629/text; Consumer Credit Safety Commission Act, H.R. 7258, 110th Cong. (2008).

32. See supra notes 17 and 18.

33. See A NEW Foundation, supra note 20, at 62.

34. See 12 U.S.C. $\$ 5493(\mathrm{~b})(3)(\mathrm{A})(2012)$.

35. Id. 
In addition to maintaining the complaint collection process, DoddFrank also requires the Bureau to provide an analysis of all of the complaints received in the Bureau's semiannual report to Congress. ${ }^{36}$ Furthermore, the CFPB must provide a "timely response" to any consumer complaint, and companies subject to the Bureau's jurisdiction are likewise required to respond in a "timely" fashion to the Bureau. ${ }^{37}$

The CFPB's complaints process, including the resulting data and analysis, is pivotal to the agency's work in three ways. ${ }^{38}$ First, it enables the Bureau to assist individual consumers with specific complaints through one unified regulatory interface. ${ }^{39}$ Second, it provides the Bureau with relevant data for performing the investigative and regulatory functions. ${ }^{40}$ Third, it provides a snapshot into consumers' issues and the financial companies that serve those consumers. ${ }^{41}$

The need to streamline consumer complaints and questions about consumer financial products was, apparently, neither a new ${ }^{42}$ nor a partisan concern. ${ }^{43}$ Since 2006, the Office of the Comptroller of the Currency ("OCC") began collaborating with state banking departments to share complaint data on a state-by-state basis. ${ }^{44}$ Republicanappointed Comptroller John C. Dugan noted in a January 2007 speech that his office received "numerous inquiries and complaints from consumers of institutions that [the Comptroller] do[es]n't regulate, and the same is true for our sister agencies at the federal and state level...

\footnotetext{
36. See 12 U.S.C. $\$ 5496(c)(4)$ (2012).

37. See 12 U.S.C. $\S 5534$ (a) (2012).

38. See Cordray, Field Hearing Prepared Remarks, supra note 4.

39. See id.

40. Id.

41. Id.

42. For example, Comptroller John C. Dugan raised these concerns as early as 2006, before the financial crisis. See, e.g., Press Release, Office of the Comptroller of the Currency, OCC, CSBS Agree on Consumer Complaint Information-Sharing Plan (Nov. 20, 2006), available at www.occ.gov/news-issuances/news-releases/2006/nr-ia2006-126.html [hereinafter OCC, 11/20/2006 Press Release].
}

43. Although the legislation creating the CFPB was passed by a Democratic legislature and signed by a Democratic president, the OCC under Republican President Bush initially promoted the efforts to streamline consumer complaints. See John C. Dugan, Comptroller of the Currency, Remarks Before the Exchequer Club and Women in Housing and Finance 20 (Jan. 17, 2007), available at www.occ.gov/newsissuances/speeches/2007/pub-speech-2007-4.pdf [hereinafter Dugan, 01/17/2007 Remarks].

44. OCC, 11/20/2006 Press Release, supra note 42. 
Unfortunately, that process takes time; is sometimes constrained by customer privacy restrictions; and has afforded few systematic opportunities to follow up on the disposition of complaints that have been referred." ${ }^{, 45}$ As a potential result of the OCC's focus on reducing consumer confusion, the Federal Financial Institutions Examination Council agreed in September 2007 to establish an inter-agency working group "to identify best practices related to the banking agencies' consumer complaint process." agency integration, though. For example, one of Dugan's suggestions to the working group was a common interagency Web portal that would route customers to the appropriate regulatory body. ${ }^{47}$

A similar desire for a common consumer interface motivated Representative Carolyn Maloney (D-N.Y.) to introduce the Financial Consumer Hotline Act of 2007. Representative Maloney's bill was designed to "establish a single, toll-free telephone number consumers can call if they have a question or complaint and want to speak to the bank's regulator." ${ }^{\text {"48 }}$ Although the bill passed in the House by a large margin, it died in the Senate. ${ }^{49}$

Consumers' confusion prior to the creation of the CFPB was not surprising: there were at least 12 federal agencies with some, occasionally overlapping, responsibility for consumer financial protection, in addition to state attorneys general and banking regulators. ${ }^{50}$ For example, a consumer with a complaint about a national

45. Dugan, 01/17/2007 Remarks, supra note 43, at 20.

46. Fed. Fin. Insts. EXAMNATION COUNCIL, ANNUAL REPort 20074 (2007), available at www.ffiec.gov/PDF/annrpt07.pdf.

47. See Press Release, Office of the Comptroller of the Currency, Comptroller Dugan Tells Conference that Consumers Will Benefit From More Unified Interagency Approach to Complaint Handling (Oct. 15, 2007), available at www.occ.gov/newsissuances/news-releases/2007/nr-occ-2007-111.html.

48. Hon. Carolyn B. Maloney of New York, Speech in the House of Representatives (Mar. 12, 2009), available at thomas.loc.gov/cgi-bin/query/

D?r111:1./temp/_r111qX5HaL.

49. The bill passed 408-1 in the House. See H.R. 4332, 110th Cong. (2007), available at https://www.govtrack.us/congress/bills/110/hr4332. However, in the Senate, the Financial Consumer Hotline Act never moved past the committee stage. See S. 3153, 110th Cong. (2008), available at www.govtrack.us/congress/bills/110/s3153.

50. These 12 agencies were: OCC, Office of Thrift Supervision, National Credit Union Administration, Federal Reserve Board, Federal Deposit Insurance Corporation, Federal Housing Finance Agency, Department of Housing and Urban Development, Veterans Administration (for VA-guaranteed mortgage loans), Internal Revenue 
bank would have needed to contact the OCC while a complaint about a state-chartered member bank would have needed to go to the bank's primary federal supervisor (either the Federal Reserve or the Federal Deposit Insurance Corporation) or state regulators. ${ }^{51}$ If the complaint dealt with a mortgage, however, it would have had to be routed to the Federal Housing Finance Agency, the Department of Housing and Urban Development, or the Veterans Administration, depending on the type of loan. ${ }^{52}$ As a result, the OCC alone reported that it both received 11,000 misdirected complaints from other agencies and referred an additional 10,000 misdirected complaints to other agencies - out of the 70,000 annual complaints opened in $2007 .^{53}$

In addition to providing consumers with one interagency regulatory interface, the data garnered through the complaints process provides input into the CFPB's enforcement arm, both on an individual level and in the aggregate. According to the CFPB Supervision and Examination Manual, which provides guidance to examiners in overseeing consumer finance companies, the complaint data helps to determine which companies should be subjected to an examination. ${ }^{54}$

In undertaking a Risk Assessment, examiners should consider both the volume and the nature of consumer complaints received by the entity or by regulatory bodies including the CFPB. In addition to shedding important light on the extent and types of concerns of consumers utilizing the entity's consumer financial products or services, complaints may provide indications of potential regulatory violations, including unfair, deceptive, or abusive acts or practices

Service, Federal Trade Commission, Department of Defense (for payday lending to military members), and Department of Justice. See Levitin, supra note 18, at 327-28.

51. Id.

52. Id.

53. H.R. 4332, The Financial Consumer Hotline Act of 2007: Providing Consumers with Easy Access to the Appropriate Banking Regulator Before the Subcomm. on Fin. Insts. and Consumer Credit of the H. Comm. on Fin. Servs., 110th Cong. 5 (2007) (statement of John G. Walsh, Chief of Staff and Public Affairs, Office of the Comptroller of the Currency), available at http://www.gpo.gov/fdsys/pkg/CHRG-110hhrg40436/pdf/CHRG-1 10hhrg40436.pdf.

54. See CONSUmer Fin. Prot. Bureau, CFPB Supervision AND EXamination MANUAL 21 (2012), available at http://files.consumerfinance.gov/f/201210_ cfpb_supervision-and-examination-manual-v2.pdf. 
(UDAAPs). How the entity handles complaints is also a key element in evaluating its compliance management system. ${ }^{55}$

If the CFPB's Consumer Response unit deems that a company has not sufficiently addressed an individual complaint, the unit can refer the issue to the Division of Supervision, Enforcement, and Fair Lending and Equal Opportunity "for further action." ${ }^{, 56}$ Moreover, the Bureau claims that the complaints that it receives also enable it to "write better rules and regulations," presumably by providing detailed information about the practices perceived as consumer-unfriendly so that the Bureau could target such practices with new guidelines. ${ }^{57}$

In keeping with the extensive debate over the CFPB's creation, the consumer complaints process has not escaped controversy, particularly its third function: providing information to the public about financial services practices. In 2012, financial services companies strenuously objected to the CFPB's proposed policy of including the name of the company in the complaint in the publicly available database. ${ }^{58}$ According to the Bureau, disclosing the number and type of complaints against individual companies was essential to providing transparency in the marketplace, including the enabling of third-party sources to rate companies on product performance and the services offered. ${ }^{59}$ By contrast, the financial services industry worried that "the inclusion of issuer identification will have serious adverse implications for consumers and card issuers alike. . . Most importantly, absent the ability to verify and properly respond to consumer accusations, the

55. Id.

56. Consumer Fin. Prot. Bureau, Semi-Annual Report of the Consumer FINANCIAL PRoteCtION BUREAU 36 (2013), available at files.consumerfinance.gov/ f/201303_CFPB_SemiAnnualReport_March2013.pdf [hereinafter CFPB, SEMIANNUAL REPORT].

57. Id.

58. As a note, confidential identifying information about consumers is not included in the Database. See Consumer Fin. Prot. BurEaU, Consumer Financial Protection Bureau Launches Consumer Complaint Database (June 19, 2012), available at http://www.consumerfinance.gov/pressreleases/consumer-financial-protection-bureaulaunches-consumer-complaint-database/. For a discussion of some of the controversy surrounding the disclosure policy, see Bureau of Consumer Fin. Prot., Docket No. CFPB-2012-0023, Disclosure OF CONSUMER COMPLAINT DATA 4-5 (2013), available at http://files.consumerfinance.gov/f/201303_cfpb_Final-Policy-Statement-Disclosureof-Consumer-Complaint-Data.pdf [hereinafter CFPB, Disclosure OF CONSUMER COMPLAINT DATA].

59. Cordray, Field Hearing Prepared Remarks, supra note 4. 
inclusion of an issuer's identity may cause unnecessary harm to the reputation and the safety and soundness of that issuer." ${ }^{\circ 0}$ After receiving comments and weighing input from industry groups, consumer advocacy organizations, and individual consumers, the CFPB officially adopted its policy of disclosing company identity in March of $2013 .{ }^{61}$ On June 19, 2012, the Consumer Complaint Database officially opened to the public. ${ }^{62}$

The Bureau began accepting consumer complaints on its first day of operations in July 2011, albeit at first only those related to credit cards. $^{63}$ The Consumer Response division has since expanded to complaints about: mortgages (on December 1, 2011); bank accounts and services, private student loans, vehicle loans, and other consumer loans (on March 1, 2012); ${ }^{64}$ credit reporting complaints (on October 22, 2012) ${ }^{65}$ and money transfers (on April 4, 2013). ${ }^{66}$ Since the Bureau opened, it has received over 100,000 consumer complaints, 91,000 in 2012 alone. $^{67}$ Consumers can submit complaints via the CFPB's website, telephone, mail, email, fax, or by referral to the agency from a third party. ${ }^{68}$

The Bureau, upon receiving the complaint, must confirm that there is a commercial relationship between the consumer and company, that the complaint is not a duplicate, and that the complaint was submitted by the identified consumer or his or her authorized representative. ${ }^{69}$

60. Letter from Consumer Bankers Ass'n, to the Consumer Fin. Prot. Bureau (Jan. 30, 2012), available at http://www.cbanet.org/documents/CBA_Credit_Card Complaint_Data_Comment_Letter_01302012.pdf.

61. CFPB, DISClOSURE OF CONSUMER COMPLAINT DATA, supra note 58.

62. Consumer fin. Prot. Bureau, Consumer Response: a Snapshot of COMPLAINTS RECEIVED 2 (2012), available at http://files.consumerfinance.gov/

f/201210_cfpb_consumer_response_september-30-snapshot.pdf [hereinafter CFPB, CONSUMER RESPONSE].

63. See CFPB, SEMI-ANNUAL RePORT, supra note 56, at 15.

64. See CFPB, CONSUMER RESPONSE, supra note 62.

65. See CFPB, SEMI-ANNUAL REPORT, supra note 56, at 15.

66. Scott Pluta, Now Accepting Money Transfer Complaints, CONSUMER FIn. PROTECTION BUREAU (Apr. 4, 2013), www.consumerfinance.gov/blog/now-acceptingmoney-transfer-complaints/.

67. CFPB, SEMI-ANNUAL REPORT, supra note 56, at 19.

68. The plurality of complaints ( $46 \%$ ) are submitted through the website; $34 \%$ are referrals. $I d$. at 20.

69. Disclosure of Certain Credit Card Complaint Data, 77 Fed. Reg. 37,558, 37,561 (June 22, 2012). 
However, the CFPB does not independently verify whether the complaint has merit, which has been another point of contention with financial services companies. ${ }^{70}$ Screened complaints are then forwarded to the appropriate company (or the appropriate regulatory agency), ${ }^{71}$ and the company must respond to the complaint within 15 days to be considered "timely." 72 If a company requires more time to respond to the complaint, it could indicate to the CFPB that resolution is "in progress" but must provide a final response within 60 days. ${ }^{73}$ Company responses fall into one of six categories: company reported closed with explanation; company reported closed with monetary relief; company reported closed with non-monetary relief; company reviewing company provided administrative response; and company reported closed (without relief or explanation). ${ }^{74}$ Once the CFPB receives the company's response, consumers have 30 days to provide feedback, including an opportunity to dispute the company's response. ${ }^{75}$

Each of these steps, including the company's timeliness, its response, and whether the consumer disputed the complaint, is recorded in the public Consumer Complaint Database, along with the consumer's ZIP code, the date of submission, and the type of complaint (i.e., the product or service and the specific kind of issue to which the complaint relates). ${ }^{76}$ The Database only includes complaints about companies subject to CFPB jurisdiction, including: "banks, thrifts, and credit unions with over $\$ 10$ billion in assets, and their affiliates, as well as certain nonbank consumer financial service providers, such as mortgage lenders, brokers and servicers; private education lenders; payday lenders; and larger participants of the consumer reporting and debt

70. CFPB, Disclosure of CONSUMER COMPlaint Data, supra note 58.

71. According to the Bureau, $11 \%$ of complaints in 2012 were referred to other regulatory agencies. CFPB, SEMI-ANNUAL REPORT, supra note 56, at 32 n.15.

72. Id. at $17 \mathrm{n} .11$.

73. Id.

74. Prior to June 1, 2012, companies could also respond with "full resolution provided," "partial resolution provided," and "closed with relief," but those categories were subsumed into "closed with monetary relief." Similarly, "no resolution provided" and "closed without relief" were incorporated into "closed with explanation." According to the CFPB, the majority of 2012 complaints were reported closed with explanation $(65 \%)$; only $2 \%$ were reported closed without relief or explanation. Id. at $32-34$.

75. Id. at 35 .

76. See Consumer Complaint Database, Consumer Fin. Protection Bureau, $\mathrm{http} / /$ www.consumerfinance.gov/complaintdatabase/technical-documentation/ (last visited Oct. 22, 2013). 
collection markets." consumer reporting companies as earning more than $\$ 7$ million in annual receipts; ${ }^{78}$ and debt collection agencies earning more than $\$ 10$ million in annual receipts from consumer debt collection activities. ${ }^{79}$

\section{The DATa Used}

The assembled statistics comparing companies is based on the 110,479 complaints and affiliated identifying information contained in the CFPB's Consumer Complaint Database. ${ }^{80}$ The analysis focuses on comparing company-specific outcomes: the likelihood of each company to receive a complaint relative to the number of products that the company sells; ${ }^{81}$ the likelihood that each company's consumers would dispute the company's response; and each company's timeliness in responding. The authors performed a series of regressions to assess whether certain demographic information correlated with the total number of complaints, the number of complaints that the consumers dispute, and the timely response rate of companies per ZCTA or ZIP code. Table 1 displays the summary statistics for the analysis, and the Appendix provides the sources and descriptions of each of the variables included.

Table 2 shows summary statistics for the various products and issues in the CFPB Database. The largest product categories - credit

77. CFPB, Strategic Plan, supra note 8.

78. CFPB Now Taking Complaints on Credit Reporting, CONSUMER FIN. PROTECTION BUREAU (Oct. 22, 2012), http://www.consumerfinance.gov/newsroom/ consumer-financial-protection-bureau-now-taking-complaints-on-credit-reporting/

79. Consumer Financial Protection Bureau Puts Companies On Notice About Harmful Debt Collection Practices, Consumer Fin. Protection Bureau (July 10, 2013), http://files.consumerfinance.gov/f/201307_cfpb_factsheet_debt-collection.pdf, at 1.

80. We lose a small number of observations (321) when trying to match ZIP codes to our available ZIP code to ZCTA database, and another small number (72) when merging with the census data. Companies with less than 10 observations were also dropped. The CFPB reports data at the ZIP code level, but most census and similar demographic data are at the ZCTA level.

81. The only product with readily available and trustworthy market share data is home mortgages, via the Home Mortgage Disclosure Act. Regulation C, now under the auspices of the CFPB, requires lending institutions to publicly disclose loan data, including the race of applicants and borrowers, all by ZIP code. See Home Mortgage Disclosure Act, FFIEC, www.ffiec.gov/hmda/default.htm (last visited June 24, 2013). 
card and mortgage complaints - comprise more than half of the Database's complaints. ${ }^{82}$ Generally, a small number of complaint issues are coded for each product except for credit card complaints, which falls into one of 33 different categories. ${ }^{83}$ The analysis includes information about the ZIP code level prevalence of various demographic factors to the CFPB Complaint Database. ${ }^{84}$ In addition to some general demographic variables of interest, including race and median income, this study also concentrated on the groups to which the CFPB is required to provide targeted assistance: military service members, ${ }^{85}$ Americans over 62 years of age, ${ }^{86}$ and students. ${ }^{87}$ The expectation was that the number of complaints from ZIP codes with high concentrations of service members, senior citizens and college or graduate students, holding all else equal, would be higher than average. Even if these groups do not experience disproportionately higher incidences of unfair, deceptive, and abusive acts or practices by financial services providers, it was expected that the CFPB's outreach to these groups would raise awareness about the ability to complain to the Bureau and/or increase the salience of the complaints process. However, since banks should largely be aware of the CFPB's differential focus on these specific groups, it was also anticipated that the number of disputed or untimely complaints would be lower for these populations (and by proxy, ZIP codes with higher concentrations of them), at least if banks had responded rationally to the threat of increased regulatory intervention by the Bureau.

Some regression specifications also include a variable for the availability of high-speed Internet access between 1999 and 2006. If locations with longstanding access to Internet source providers registered disproportionately more complaints, it could be suspected that the CFPB was merely cherry-picking the Internet-savvy, as the plurality of complaints the Bureau receives are web-based. ${ }^{88}$

\footnotetext{
82. For summary statistics, see Tables 1 and 2.

83. Id.

84. See Appendix.

85. Via an Office of Service Member Affairs. See 12 U.S.C. $\S 5493(e)(1)$ (2012). Dodd-Frank specifically authorizes the Director of the CFPB to locate such an office "near military bases, military treatment facilities, or other similar military facilities." Id.

86. Via an Office of Financial Protection for Older Americans. See 12 U.S.C. § $5493(\mathrm{~g})(1)$.

87. Via the Private Education Loan Ombudsman. See 12 U.S.C. $§ 5535$ (a) (2012).

88. See supra note 68.
} 
One of the chief complaints that financial service providers lodged when the CFPB announced plans to publicize its complaint Database was the lack of scale to normalize the data. ${ }^{89}$ For example, a bank with 100,000 open accounts and 500 complaints might look worse than a bank with 1,000 accounts outstanding and 200 complaints, at least if consumers were not informed of each bank's respective size. Unfortunately, the CFPB does not yet offer a way to normalize the number of complaints in the Database, and the only independently verifiable market share data that was accessible for this data was for mortgage complaints. The Home Mortgage Disclosure Act ("HMDA") requires certain financial institutions to report home lending activity, which provides a baseline for the number of mortgages that each bank creates. $^{90}$ However, because of the lagging releases of HMDA data, the data is based on the flow of home mortgages that particular companies issued as a proxy for the stock of those companies' 2013 market share of outstanding mortgages.

The proxy regarding outstanding home mortgages could fail for several reasons, including the delay between HMDA data collection and release, and the mismatch between mortgage originators and servicers. The time lag itself is not of major concern because many of the mortgage issue complaints in 2012-2013 likely dated to approvals in years past. ${ }^{91}$ A potentially more significant concern is that mortgage originators and servicers are not always identical. For example, if Bank of America consistently sells all of its mortgages to Citibank, our calculation would overstate Bank of America's number of complaints per mortgage because it would not account for the complaints filed once Citibank owned the mortgages. Without further disclosures from financial service providers, the HMDA data should at least begin to

89. See, e.g., Letter from Nessa Feddis, Vice President and Senior Counsel, Ctr. for Regulatory Compliance, to Monica Jackson 3 (July 19, 2012), available at http://www.efpbmonitor.com/files/2012/07/clConsumercomplaintdata2012July.pdf [hereinafter Feddis Letter].

90. See Home Mortgage Disclosure Act, FFEIC (Sept. 23, 2013), http://www.ffiec.gov/hmda/hmdaproducts.htm.

91. As well, none of the companies listed in Table 4 below were subject to a major merger between 2011 and 2013. See, e.g., Alan Kline, Bank Population Shrinks Rapidly Amid Lull in Startups, AM. BANKER (Sept. 5, 2013), available at http:/www.americanbanker.com/issues/178_172/bank-population-shrinks-rapidlyamid-lull-in-startups-1061817-1.html. 
provide a baseline to assess the likelihood that a recent mortgage will give rise to a consumer complaint.

There are a few more limitations to the data and its results. For example, financial service providers have complained that the data is not representative because they merely measured the number of complainants, not the number of actual unfair or deceptive practices. ${ }^{92}$ For example, if Bank of America customers were identifiably different in some way from Citibank customers such that the former were more likely to complain than the latter, there might be a significant difference in the number of complaints but not in the incidence of unfair practices. Additionally, the Database does not differentiate between "major" and "minor" complaints. ${ }^{93}$ As a result, even if two banks were to have the same number of complaints relative to number of mortgages outstanding, for instance, one bank might still be engaging in worse practices, but that distinction would not be apparent from the CFPB data. Furthermore, because the CFPB's regulatory authority over banks is limited to those with over $\$ 10$ billion in assets, complaints about smaller banks are excluded from the Database, which might distort consumer perception of the relative performance of smaller and bigger companies. Finally, companies were also concerned that consumer complaints entered into the Database might not be meritorious because the CFPB does not verify the accuracy of each complaint, thereby skewing the perception of each company's performance. ${ }^{94}$

These issues, while presumably of concern to the CFPB, are not particularly problematic for our analysis. First, as discussed above, the Bureau does verify that the consumer has a business relationship with the company in question, so only actual disgruntled customers can submit complaints. ${ }^{95}$ More importantly, the analysis herein on company variation does not implicate most of the aforementioned concerns. For example, it is unlikely that the customers of any one company would be more or less inclined to concoct frivolous claims, especially given the size and national scale of the companies under review, which allow for randomized, representative data. This is aside from the unlikelihood that most complainants would even dispute a company's response to a truly frivolous complaint, given the additional time that such disputes

\footnotetext{
92. See Feddis Letter, supra note 89.

93. See id.

94. Id.

95. See Disclosure of Certain Credit Card Complaint Data, 77 Fed. Reg. 37,558, 37,561 (June 22, 2012).
} 
require. Moreover, even if all of the complaints against a particular company were frivolous or "minor," it does not excuse that company from providing timely responses. If anything, the more frivolous or minor the complaint, the easier it should be for the company to respond quickly.

\section{THE RESUltS}

\section{A. The COMPANY-SPECIFIC Results}

Table 3 lists the 27 companies with a significantly higher proportion of untimely responses than average, at the $10 \%$ significance level. Among these, the least timely company was the Prudent Law Group, a loan modification specialist, which responded late to $92 \%$ of its 12 complaints. Among the larger institutions, Bank of America, Citibank, and PNC Bank were significantly less timely than average, with untimely response rates of $6 \%, 4 \%$, and $5 \%$, respectively.

Table 4 analogously reports the list of companies with a statistically higher than average proportion of disputed company responses, ranked by the proportion disputed. ${ }^{96}$ While the sample size for most companies is relatively small, Table 4 shows that consumers disputed significantly more responses from 17 companies, including some of the largest banks in the U.S., including Wells Fargo (24\% disputed) and Bank of America ( $22 \%$ disputed). ${ }^{97}$ Interestingly, the companies with the largest percentage of disputed responses were BMW Financial Services (53\% disputed) and Charles Schwab Bank (40\% disputed). ${ }^{98}$ However, these rates might represent higher consumer expectations associated with the companies' positions at the upper end of the consumer finance market.

In Table 5, the HMDA data described above was used to assess the number of mortgage complaints per mortgage that originated for the banks with the largest number of CFPB records. Given the methodology, it would be inaccurate to say that, for example, $25 \%$ of

96. All consumer complainants have the opportunity to dispute the company's response within 30 days of receiving it. See CFPB, SEMI-ANNUAL REPORT, supra note 56 , at 35 . From Table 1, the mean number of disputed responses across all categories of products and services was $21 \%$, which is identical to the CFPB's reported percentage in October 2012. See CFPB, CONSUMER RESPONSE, supra note 62, at 4.

97. See Table 4.

98. Albeit these are the two smallest sample sizes, consisting of 19 and 20 observations, respectively, in the data set. 
OneWest Bank's outstanding mortgages generated complaints, as some of the 1,113 mortgage complaints could have been lodged for products sold in multiple years past and not in 2011 alone. However, the number of mortgages that originated in 2011 provides some basis for normalizing the number of complaints received, thus serving as a benchmark for comparing the banks. By this metric, OneWest performs far worse than any other bank. ${ }^{99}$ Among the banks with over one million mortgages that originated in 2011, Bank of America received the highest percentage of complaints. ${ }^{100}$

\section{B. Results Based on ZIP Code Demographics, Products, AND SPECIFIC ISSUES}

The remainder of the analysis is not company-specific, and instead focuses on the demographic information from ZIP codes with reported complaints and the products and specific issues about which consumers complained. Table 6 displays the results for a regression of the $\log$ of the total number of mortgage complaints over the number of households with a mortgage for ZCTAs with at least one registered complaint in the Database. Our model for Table 6 is

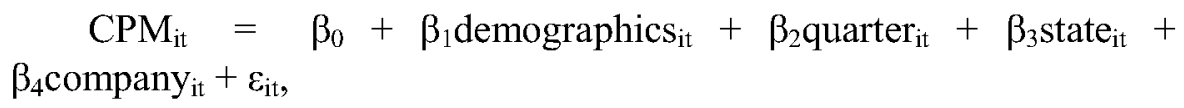

where $C P M_{i t}$ is the log of mortgage complaints per 2011 mortgage originations at the ZIP code level, and demographics it is a vector of demographic characteristics. ${ }^{101}$ Quarter-fixed effects control for

99. However, our ranking measure of complaints per mortgages originated in 2011 will overstate the tendency for the stock of a company's outstanding mortgages to generate complaints if that company's market share of 2011 originations was lower than its origination market share in the past. We note that OneWest was predominantly formed with the then bankrupt IndyMac's assets in 2009, and that Bank of America purchased Countrywide (a massive mortgage lender) in 2008.

100. See Table 5 .

101. Fixed effects are $\{0,1\}$ variables that are included to control for unobserved heterogeneity (an unobserved quantity that could influence the relationship between the dependent and independent variables). For example, if a certain demographic characteristics were (1) not included as controls in the regression, (2) constant over time at the state level, and (3) influenced the relationship between mortgage complaints and an included variable, the coefficient on the included variable would be biased in the regression. State fixed effects control for this possibility. See Benjamin A. Lindy, The Impact of Teacher Collective Bargaining Laws on Student Achievement: Evidence from 
heterogeneity in complaints across time while state-fixed effects control for heterogeneity at the state level. In the full specification, companyfixed effects are included to control for idiosyncratic company effects.

Note that our reduced-form model cannot prove causality: for example, if ZIP codes with higher proportions of senior citizens have more complaints per mortgage, we cannot determine if mortgage companies are treating older borrowers worse than younger ones, or if senior citizens are just more likely to complain to the CFPB. However, even in the absence of causal evidence, the results at least suggest that mortgage lenders might need to show increased care toward certain populations.

Table 6 shows that even after controlling for quarter-, state-, and company-fixed effects, the complaint rates are statistically higher in ZIP codes with higher concentrations of African-Americans, Hispanics, and seniors. ${ }^{102}$ For the most controlled specifications, the complaint rate falls statistically as the median income of a ZIP code rises but increases with the median income of African-American or Hispanic residents. However, areas with higher concentrations of active duty military are significantly more likely to complain only in the specifications that do not control for the number of Internet service providers ("ISPs"), rural concentration, and foreclosure risk score.

Areas with better-educated populations (i.e., high school and college graduates) are significantly more likely to report mortgage complaints. ZCTAs with high employment rates appear to also have larger numbers of complaints, but the level of significance drops once the state- and company-fixed effects are added.

A somewhat surprising result is in the final column specification, which shows a negative and statistically significant coefficient estimated for a ZIP code's number of ISPs. These authors predicted that borrowers with faster Internet access would be able to file complaints online at a higher rate than borrowers without such access. Finally, ZIP codes with a higher foreclosure risk score had statistically lower complaints per mortgage. This foreclosure finding is potentially troubling for the CFPB and a potential cause of action for consumer advocates because it suggests that areas with homes at the greatest risk

A New Mexico Natural Experiment, 120 YALE L.J. 1130, 1147 (2011) (explaining fixed effects).

102. The census data track senior citizens over the age of 65 rather than 62 . 
of foreclosure are not sufficiently availing themselves of the CFPB's complaint system.

Next, Table 7 provides results pertaining to whether a complaint was resolved in a timely manner across company and product. Here, the individual level data is coded as a 0 for an undisputed complaint and a 1 for a disputed complaint, and a logit regression ran the individual data. The specification of fixed effects is the same as in Table 6 but includes issue-fixed effects, enabled by the use of individual data. The only independent variable that produced significant results is college enrollment: ZCTAs with higher levels of college students were significantly more likely to report untimely responses from companies. Because students are a particular focus of the CFPB, this result is both unexpected and troubling. Higher proportions of Blacks and Hispanics were positively correlated with untimeliness of the company's response, albeit not significantly.

Table 7 also disaggregates timeliness by product and by specific complaint within each product type. The timeliness of corporate responses for each product listed in the table is compared to mortgages, the omitted category. Thus, companies responding to bank account or service and credit card complaints were significantly more likely to be timely in their response than mortgage companies. Companies were also more likely to be timely in responding to student loan complaints although the level of significance declines once company-fixed effects are included.

Similarly, the regressions for issues within each product type compare the timeliness of response to the largest issue (determined by the number of complaints registered with the CFPB) in each category. ${ }^{103}$ According to the analysis, credit card companies seem to discriminate the most based on issue type ${ }^{104}$ Complaints about the Annual Percentage Rate ("APR") or interest rate and the payoff process were significantly more likely to receive a timely response while complaints about credit card or debt protection, identity theft/fraud/embezzlement, and sale of account were significantly less likely to receive a timely response, relative to credit card billing disputes. ${ }^{105}$ Although it seems

103. See infra Table 7.

104. See id. (showing the coefficients for product category); see also infra Table 9 (showing the coefficients for a subset of the issues within those product categories). Due to space restrictions, the issue coefficients found in Table 9 are from the specification in the final column of Table 7.

105. See infra Table 9. 
counterintuitive that companies would not respond in a timely fashion to fraud claims in particular, as they can pose a more endemic and expensive problem for companies if not quickly resolved, it is possible that only certain types of complaints would be routed through the CFPB rather than the credit card seller directly. Regardless, the divergence in timeliness among these products suggests that at least credit card companies are selective in prioritizing their timely responses to customer complaints.

Table 8 contains an analogous logit regression of whether a complaint was disputed on the same demographic factors described above. These results must be taken with an extra degree of caution, as consumers may complain regardless of whether the company responded in a satisfactory manner. We found that areas with more senior citizens were more likely to dispute company responses. One hypothesis is that many individuals in that age bracket are retirees, and therefore, have more time to pursue complaints. It also might suggest that the CFPB's Office of Older Americans may need to make a more concerted effort to work with companies before the dispute stage. Among the CFPB's other target groups, higher levels of military employment in a ZIP code positively correlate with the number of disputes in that area, but not significantly so. At the same time, college enrollment is negatively correlated with the number of disputes but not significantly. Similarly, higher numbers of college graduates are more likely to dispute complaints, albeit with weaker significance once accounting for additional variables and multiple fixed effects. More rural areas are also significantly more likely to dispute responses, although the coefficients are not large. As in Table 6, the Foreclosure Risk Score is negatively correlated with the number of disputes, although only at a modest level of significance.

Table 8 displays the number of responses disputed among each product category. Again, relative to mortgages, consumers were significantly less likely to dispute company responses to complaints about bank account or service, credit card, and student loan products. Among product issues, consumers were significantly less likely to dispute company responses to complaints about bank account funds being too low, credit card advertising and marketing, credit card billing statements and related fees, and credit monitoring or identity protection from credit reporting agencies. However, consumers were significantly more likely to dispute credit card company responses about bankruptcy, cash advances, collection debt disputes, credit card or debt protection, a 
change in credit line or credit reporting, and credit reporting agency responses about company investigations and improper use of the credit report. Although these results do not suggest one clear, consistent pattern, one possible explanation is that consumers are less satisfied with company responses when dealing with more bureaucratic or complex processes (i.e., bankruptcy or credit reporting) than with issues that are more individualized, simplistic, and easily resolved (i.e., fee assessments).

\section{RECOMMENDATIONS}

Without commenting specifically on the consumer finance industry's objections to the level of public disclosure, the CFPB's Consumer Complaint Database is unquestionably a rich source of data. ${ }^{106}$ The total number of complaints and whether the proposed company response was timely and disputed provide a snapshot of how both the CFPB and the companies that it regulates are performing. The analysis herein incorporates a number of dimensions to determine who is complaining and how companies are responding. ${ }^{107}$ The results suggest that the CFPB might need to conduct more outreach in areas where homeowners have the highest risk of foreclosure given the lower number of complaints in ZIP codes with higher foreclosure risk scores, contrary to expectations about who would avail themselves of the complaint process (i.e., those facing foreclosure). ${ }^{108}$ Furthermore, the CFPB might need to assert more pressure on companies serving older Americans, as areas with more seniors were significantly more likely to dispute company resolutions. ${ }^{109}$

Likewise, the CFPB's Private Education Loan Ombudsman should be concerned that company responses were significantly more likely to be untimely in areas with higher concentrations of students. ${ }^{110}$ The analysis also suggests that some of the biggest companies in the consumer finance industry have yet to focus on the potential consequences - both regulatory and public relations - for inadequately responding to complaints lodged with the CFPB. ${ }^{111}$ Bank of America, Citibank, PNC, and OneWest Bank were significantly more like likely

\footnotetext{
106. See Cordray, Field Hearing Prepared Remarks, supra note 4.

107. See supra Part IV; see also infra Tables 3-10 (analyzing statistical results).

108. See supra Part IV; infra Table 6.

109. See infra Table 8.

110. See infra Table 7.

111. See infra Table 3.
} 
than the average bank to respond in an untimely manner. ${ }^{12}$ Moreover, consumers of several major national financial institutions, including Wells Fargo and Bank of America, were significantly more likely to dispute the company's response to their complaints. ${ }^{113}$ It should also be worrisome to executives at, and potential customers of, OneWest Bank, HSBC, Nationstar Mortgage, and Bank of America, that the volume of mortgage complaints that those companies received out of the number of mortgages that they sold were disproportionately larger compared to that of other large companies. ${ }^{114}$ The divergent rates of timeliness in responding to complaints based on the product and issue also suggest that the CFPB needs to stress the importance of timely responses to all complaints, not just those that a company deems to be higher priorities. ${ }^{115}$ In addition, to the extent that responses from mortgage companies and any financial institution regarding more complex products or issues result in more consumer disputes, the CFPB may wish to work with companies and consumers at the initial complaint stage to preempt any problems that result from disputed responses.

\section{CONCLuSION}

Our analysis demonstrates that the CFPB's decision to disclose the details about the complaints that it receives indeed serves the Bureau's goal of enabling researchers to "analyze, augment, and build" on the Consumer Complaint Database. ${ }^{116}$ The results of the study reveal significant differences among financial services providers on how timely they are in responding to complaints, and the extent to which consumers dispute those responses. Moreover, the underlying products being complained about and the issues consumers had with those products drove differences in company response time and percentage of disputes. Likewise, the demographics of a complainant's ZIP code also drove significant difference in these key company variables. Given the CFPB's power to regulate financial services providers, and its stated reliance on the Consumer Complaint Database as a key source of information about the marketplace, companies should heed these results

\footnotetext{
112. See id.

113. See infra Table 4.

114. See infra Table 5.

115. See infra Tables 2 and 9.

116. See Cordray, Field Hearing Prepared Remarks, supra note 4.
} 
and strive to improve their response processes for all consumers. Additionally, the CFPB should work to ensure that all consumers know about and have access to the complaint system, at the very least as a means of strengthening the feedback loop. 


\section{APPENDIX: VARIABLES INCLUDED IN THE ANALYSIS}

- Disputed: The complaints disputed by consumers within the CFPB's 30-day window once the company's response is received, as reported in the Consumer Complaint Database

- Not Timely: The complaints to which the company did not respond within the CFPB's 15-day window once the consumer complaint was transmitted, as reported in the Consumer Complaint Database

- Proportion Black: By ZCTA, the respondents who reported "Black" or "African-American" as their only race, as reported in the 2007-2011 American Community Survey 5-Year Estimates

- Proportion Hispanic: By ZCTA, the respondents who reported Hispanic or Latino origin (regardless of race), as reported in the 2007-2011 American Community Survey 5-Year Estimates

- Median Income (Black): By ZCTA, the household median income in the past 12 months (in 2011 inflation-adjusted dollars) as reported in the 2007-2011 American Community Survey 5Year Estimates, for respondents reporting one race: Black or African American

- Median Income (Hispanic): By ZCTA, the household median income in the past 12 months (in 2011 inflation-adjusted dollars) as reported in the 2007-2011 American Community Survey 5Year Estimates, for respondents reporting Hispanic or Latino origin

- Median Income (All): By ZCTA, the household median income in the past 12 months (in 2011 inflation-adjusted dollars) as reported in the 2007-2011 American Community Survey 5-Year Estimates by all respondents

- Seniors: By ZCTA, the percent of the total population aged 65 and older, as reported in the 2007-2011 American Community Survey 5-Year Estimates

- Military Employment: By ZCTA, employment status reported as in labor force: Armed Forces, as reported in the 2007-2011 American Community Survey 5-Year Estimates

- College Enrollment: By ZCTA, the percent of the total population enrolled in college or graduate school, as reported in the 2007-2011 American Community Survey 5-Year Estimates

- High School Graduates: By ZCTA, the percentage of those who reporting being both 25 years or older and a high school 
graduate (or high school equivalent) out of the ZCTA's total population, as reported in the 2007-2011 American Community Survey 5-Year Estimates

- College Graduates: By ZCTA, the percentage of those who reported being 25 years or older and having a bachelor's degree out of the ZCTA's total population, as reported in the 2007-2011 American Community Survey 5-Year Estimates

- Unemployment Rate: By ZCTA, the estimated unemployment rate for those 16 years of age or older, as reported in the 20072011 American Community Survey 5-Year Estimates

- Number ISPs: The number of high-speed ISPs per ZIP code in 2006, as reported by the FCC

- Rural (RUCA Score): The score of the rural or urban concentration within a ZIP code, whereby a score of 1 represents a "metropolitan area core: primary flow within an urbanized area," and a score of 10 represents "a rural area: primary flow to a tract outside an urbanized area or urban cluster." $" 17$

- Foreclosure Risk Score: The foreclosure "risk score" at the ZIP code level, based on measures of subprime lending, foreclosures, delinquency, and vacancies, as calculated by the Local Initiatives Support Corporation ("LISC"), whereby the ZIP codes are scored in relative terms, such that the highest-risk area within each state receives a score of 100, and each other ZIP code is assigned a score based on its relative risk profile (i.e., a ZIP code with half of the risk of the highest-risk area would receive a score of 50). ${ }^{118}$

117. The Census Bureau created the Rural Urban Community Areas (RUCA) scores, which are available at the Rural Health Research Center's website. See RUCA Data, RURAL HEALth RES. CENTER, depts.washington.edu/uwruca/ruca-data.php (last visited Feb. 26, 2014).

118. For more information and raw scores, see LISC Foreclosure Risk Scores Data, March 2013, FORECLOSURE-RESPONSE.ORG (July 2013), www.foreclosureresponse.org/maps_and_data/lisc_data.html. 
TABLE 1: SUMMARY STATISTICS

\begin{tabular}{|lllllll|}
\hline Variable & Level & Obs & Mean & $\begin{array}{l}\text { Std. } \\
\text { Dev }\end{array}$ & Min & Max \\
Not Timely & Individual & 110,479 & 0.03 & 0.16 & 0 & 1 \\
Disputed & Individual & 110,479 & 0.21 & 0.41 & 0 & 1 \\
$\begin{array}{l}\text { Complaints per } \\
\text { Mortgage* }\end{array}$ & ZCTA & 7,865 & 0.00 & 0.01 & 0 & 0.44 \\
$\begin{array}{l}\text { Proportion Black } \\
\text { Proportion }\end{array}$ & ZCTA & 15,493 & 0.10 & 0.17 & 0 & 1.00 \\
$\begin{array}{l}\text { Hispanic } \\
\text { Median Income }\end{array}$ & ZCTA & 15,493 & 0.10 & 0.17 & 0 & 1.00 \\
(Black) & 10,779 & 4.81 & 3.16 & 0.30 & 24.78 \\
$\begin{array}{l}\text { Median Income } \\
\text { (Hispanic) }\end{array}$ & ZCTA & 12,391 & 5.24 & 3.06 & 0.35 & 24.69 \\
$\begin{array}{l}\text { Median Income } \\
\text { (All) }\end{array}$ & ZCTA & 15,433 & 5.76 & 2.42 & 0.86 & 24.22 \\
$\begin{array}{l}\text { Proportion } \\
\text { Seniors }\end{array}$ & ZCTA & 15,493 & 0.18 & 0.07 & 0 & 1.00 \\
$\begin{array}{l}\text { Proportion } \\
\text { Military }\end{array}$ & ZCTA & 15,480 & 0.01 & 0.05 & 0 & 0.99 \\
$\begin{array}{l}\text { Employment } \\
\text { Proportion }\end{array}$ & & & & & & \\
College & ZCTA & 15,493 & 0.08 & 0.07 & 0 & 1.03 \\
High School & ZCTA & 15,493 & 0.19 & 0.08 & 0 & 1.00 \\
College Graduate & ZCTA & 15,493 & 0.20 & 0.13 & 0 & 1.00 \\
$\begin{array}{l}\text { Unemployment } \\
\text { Rate }\end{array}$ & ZCTA & 15,480 & 0.09 & 0.05 & 0 & 0.77 \\
ISP & ZIP & 15,094 & 8.77 & 3.30 & 0 & 21 \\
RUCA & ZIP & 16,759 & 2.78 & 2.90 & 1 & 10.60 \\
$\begin{array}{l}\text { Foreclosure Risk } \\
\text { Score }\end{array}$ & ZIP & 14,886 & 0.09 & 0.14 & 0 & 1.00 \\
\hline & & & & & \\
\hline
\end{tabular}

* For ZCTAs with at least one mortgage complaint and not more mortgage complaints than households with mortgages listed by the census. 


\section{TABLe 2: Product Types AND Issues}

Bank Account or Service

\begin{tabular}{|lll|}
\hline Issue & Complaints & Percentage \\
Account opening, closing, or management & 7,026 & 40.58 \\
$\begin{array}{l}\text { Deposits and withdrawals } \\
\text { Making/receiving payments, sending }\end{array}$ & 4,904 & 28.32 \\
money & 1,482 & \\
Problems caused by my funds being low & 2,859 & 8.56 \\
Using a debit or ATM card & 1,043 & 16.51 \\
Total $^{119}$ & 17,314 & 6.02 \\
\hline
\end{tabular}

Consumer Loan

\begin{tabular}{|lll|}
\hline Issue & Complaints & Percentage \\
Account terms and changes & 174 & 5.88 \\
Managing the line of credit & 227 & 7.67 \\
Managing the loan or lease & 1,445 & 48.82 \\
Problems when you are unable to pay & 624 & 21.08 \\
Shopping for a line of credit & 61 & 2.06 \\
Shopping for a loan or lease & 124 & 4.19 \\
Taking out the loan or lease & 305 & 10.30 \\
Total & 2,960 & 100 \\
\hline
\end{tabular}

Credit Reporting

\begin{tabular}{|lll|}
\hline Issue & Complaints & Percentage \\
Credit monitoring or identity protection & 209 & 3.46 \\
Credit reporting company's investigation & 867 & 14.33 \\
Improper use of my credit report & 349 & 5.77 \\
Incorrect information on credit report & 3,907 & 64.59 \\
Unable to get credit report/credit score & 717 & 11.85 \\
Total & 6,049 & 100 \\
\hline
\end{tabular}

119. This and the totals in the following tables equal exactly $100 \%$ when accounting for rounding error from the use of two digits. 
Credit Card

\begin{tabular}{|lll|}
\hline Issue & Complaints & Percentage \\
APR or interest rate & 2,235 & 10.17 \\
Advertising and marketing & 498 & 2.27 \\
Application processing delay & 134 & 0.61 \\
Arbitration & 74 & 0.34 \\
Balance transfer & 268 & 1.22 \\
Balance transfer fee & 57 & 0.26 \\
Bankruptcy & 97 & 0.44 \\
Billing disputes & 3,467 & 15.78 \\
Billing statement & 611 & 2.78 \\
Cash advance & 75 & 0.34 \\
Cash advance fee & 60 & 0.27 \\
Closing/Cancelling account & 1,403 & 6.39 \\
Collection debt dispute & 834 & 3.80 \\
Collection practices & 938 & 4.27 \\
Convenience checks & 38 & 0.17 \\
Credit card protection / Debt protection & 792 & 3.61 \\
Credit determination & 749 & 3.41 \\
Credit line increase/decrease & 663 & 3.02 \\
Credit reporting & 1,699 & 7.73 \\
Customer service / Customer relations & 566 & 2.58 \\
Delinquent account & 276 & 1.26 \\
Forbearance / Workout plans & 201 & 0.92 \\
Identity theft / Fraud / Embezzlement & 1,472 & 6.70 \\
Late fee & 897 & 4.08 \\
Other & 1,130 & 5.14 \\
Other fee & 577 & 2.63 \\
Overlimit fee & 64 & 0.29 \\
Payoff process & 649 & 2.95 \\
Privacy & 104 & 0.47 \\
Rewards & 527 & 2.40 \\
Sale of account & 55 & 0.25 \\
Transaction issue & 486 & 2.21 \\
Unsolicited issuance of credit card & 270 & 1.23 \\
Total & 21,966 & 100 \\
\hline
\end{tabular}


Money Transfers

\begin{tabular}{|lll|}
\hline Issue & Complaints & Percentage \\
Fraud or scam & 6 & 17.14 \\
Incorrect/missing disclosures or info & 1 & 2.86 \\
Money was not available when promised & 9 & 25.71 \\
Other service issues & 2 & 5.71 \\
Other transaction issues & 15 & 42.86 \\
Wrong amount charged or received & 2 & 5.71 \\
Total & 35 & 100 \\
\hline
\end{tabular}

Mortgage

\begin{tabular}{|lll|}
\hline Issue & Complaints & Percentage \\
Application, originator, mortgage broke & 3,898 & 6.68 \\
Credit decision / Underwriting & 1,254 & 2.15 \\
$\begin{array}{l}\text { Loan modification, collection, } \\
\text { foreclosure }\end{array}$ & 34,785 & 59.58 \\
$\begin{array}{l}\text { Loan servicing, payments, escrow } \\
\text { account }\end{array}$ & 14,745 & 25.26 \\
$\begin{array}{l}\text { Other } \\
\text { Settlement process and costs }\end{array}$ & 1,801 & 3.08 \\
Total & 1,898 & 3.25 \\
\end{tabular}

Student Loan

\begin{tabular}{|lll|}
\hline Issue & Complaints & Percentage \\
Getting a loan & 140 & 3.71 \\
Problems when you are unable to pay & 1,125 & 29.81 \\
Repaying your loan & 2,509 & 66.48 \\
Total & 3,774 & 100 \\
\hline
\end{tabular}


TABle 3: Company-SPECific Proportion of Complaints With UNTIMELY COMPANY RESPONSES

\begin{tabular}{|llll|}
\hline Company & Observations & $\begin{array}{l}\text { Percent } \\
\text { Untimely }\end{array}$ & P-Value ${ }^{120}$ \\
Prudent Law Group & 12 & 0.92 & 0.00 \\
Mercedes-Benz Financial & 12 & 0.58 & 0.00 \\
Services & & & \\
Statebridge Company & 51 & 0.31 & 0.00 \\
Vantium Capital & 21 & 0.24 & 0.04 \\
Quantum Servicing Company & 18 & 0.22 & 0.07 \\
UMB Bank & 33 & 0.21 & 0.01 \\
BancorpSouth Bank & 19 & 0.21 & 0.07 \\
Residential Credit Solutions & 115 & 0.18 & 0.00 \\
Regions & 647 & 0.17 & 0.00 \\
Mortgage Investors & 41 & 0.17 & 0.02 \\
Corporation & & & \\
Amerisave & 70 & 0.16 & 0.00 \\
Franklin Credit Management & 27 & 0.15 & 0.09 \\
USAA Savings & 491 & 0.14 & 0.00 \\
Morgan Stanley & 65 & 0.14 & 0.01 \\
Bayview Loan Servicing, & 183 & 0.08 & 0.01 \\
LLC & & & \\
First Niagara Bank & 170 & 0.08 & 0.01 \\
People's United Bank & 90 & 0.08 & 0.07 \\
OneWest Bank & 1,147 & 0.07 & 0.00 \\
MetLife Bank & 179 & 0.07 & 0.02 \\
\hline & & & \\
\hline
\end{tabular}

120. Here, the null hypothesis is that the company's proportion of untimely responses is equal to the average proportion of untimely responses across all companies. A low p-value indicates that the null hypothesis is statistically unlikely. A p-value of 0.05 shows that there is a 1 in 20 chance of finding a value as or more extreme as the observed value given the null hypothesis. A commonly used measure of a "low" p-value is one lower than 0.10 or 0.05 (hence the references to $10 \%$ significance and 5\% significance). See generally David MOORE, THE BASIC PRACTICE OF STATISTICS 371-77 (2009) (explaining hypothesis testing). 


\begin{tabular}{|llll|}
\hline Carrington Mortgage & 148 & 0.07 & 0.05 \\
Loan Care & 95 & 0.07 & 0.08 \\
Bank of America & 23,493 & 0.06 & 0.00 \\
Nationstar Mortgage & 1,819 & 0.06 & 0.00 \\
M\&T Bank & 636 & 0.06 & 0.00 \\
Comerica & 145 & 0.06 & 0.08 \\
PNC Bank & 2,030 & 0.05 & 0.00 \\
Citibank & 7,519 & 0.04 & 0.00 \\
\hline
\end{tabular}

Notes: The companies shown have a significantly higher proportion of untimely responses than average (defined at the $10 \%$ significance level). The table is sorted by proportion of untimely responses. The final column shows the p-value from a test of the difference in the proportion of untimely responses from the average proportion of untimely responses. Companies with fewer than 10 observations, after excluding "In Progress" complaints, were not tested. 
Table 4: Company-SPECIFIC Proportion of CoMPany Responses

DISPUTED BY CONSUMER

\begin{tabular}{|llll|}
\hline Company & Observations & $\begin{array}{l}\text { Percent } \\
\text { Disputed }\end{array}$ & $\begin{array}{l}\text { P- } \\
\text { Value }\end{array}$ \\
BMW Financial Services & 19 & 0.53 & 0.02 \\
Charles Schwab Bank & 20 & 0.45 & 0.05 \\
Cash Call & 50 & 0.40 & 0.01 \\
ChexSystems & 39 & 0.38 & 0.04 \\
Banco Popular de Puerto & 97 & 0.37 & 0.00 \\
Rico & & & \\
Banco Popular North & 45 & 0.36 & 0.06 \\
America & & & \\
Santander Consumer USA & 225 & 0.32 & 0.00 \\
State Farm Bank & 75 & 0.32 & 0.05 \\
Toyota Motor Credit & 56 & 0.32 & 0.09 \\
Corporation & & & \\
Comerica & 145 & 0.28 & 0.07 \\
Navy FCU & 301 & 0.26 & 0.07 \\
The Huntington National & 270 & 0.26 & 0.09 \\
Bank & & & \\
Amex & 1,439 & 0.25 & 0.00 \\
TD Bank & 1,101 & 0.25 & 0.02 \\
Wells Fargo & 14,476 & 0.24 & 0.00 \\
Ocwen & 5,331 & 0.23 & 0.02 \\
Bank of America & 23,493 & 0.22 & 0.01 \\
\hline
\end{tabular}

Notes: The companies shown have a significantly higher proportion of disputed complaints than average (defined at the 10\% significance level). The table is sorted by proportion of disputed responses. The final column shows the p-value from a test of the difference in the proportion of disputed responses from the average proportion of disputed responses. Companies with fewer than 10 observations, after excluding "In Progress" complaints, were not tested.

121. See supra note 120 . 
Table 5: Mortgage Complaints Per Mortgage Originated, LARGEST BANKS

\begin{tabular}{|c|c|c|c|}
\hline Bank & $\begin{array}{l}\text { CFPB } \\
\text { Mortgage } \\
\text { Complaints* }\end{array}$ & $\begin{array}{l}\text { Number of } \\
2011 \text { Mortgages } \\
\text { Originated }^{* *}\end{array}$ & $\begin{array}{l}\text { Complaints per } \\
\text { Mortgage } \\
\text { Originated in } 2011\end{array}$ \\
\hline $\begin{array}{l}\text { OneWest } \\
\text { Bank }\end{array}$ & 1,113 & 4,507 & 0.247 \\
\hline HSBC & 1,402 & 15,720 & 0.089 \\
\hline $\begin{array}{l}\text { Nationstar } \\
\text { Mortgage }\end{array}$ & 1,817 & 33,639 & 0.054 \\
\hline $\begin{array}{l}\text { Bank of } \\
\text { America }\end{array}$ & 17,502 & $1.00 \mathrm{E}+06$ & 0.017 \\
\hline Citibank & 2,706 & 189,222 & 0.014 \\
\hline $\begin{array}{l}\text { JPMorgan } \\
\text { Chase }\end{array}$ & 5,805 & $1.00 \mathrm{E}+06$ & 0.006 \\
\hline $\begin{array}{l}\text { SunTrust } \\
\text { Bank }\end{array}$ & 1,038 & 184,056 & 0.006 \\
\hline Wells Fargo & 9,499 & $2.10 \mathrm{E}+06$ & 0.004 \\
\hline
\end{tabular}

* Up to May 1, 2013

** 2011 HMDA data

Notes: The listed banks are those with the largest number of CFPB records. 
TABLe 6: Regressions OF LOG OF MORTGage COMPLAINTS PER MORTGaGE ORIGINATED ON DEMOGRAPHIC FACTORS OF ZIP CODE

\begin{tabular}{|c|c|c|c|c|c|}
\hline & (1) & (2) & (3) & (4) & (5) \\
\hline Proportion Black & $\begin{array}{l}1.033 * * * \\
(0.076)\end{array}$ & $\begin{array}{l}0.986 * * * \\
(0.089)\end{array}$ & $\begin{array}{l}1.015 * * * \\
(0.083)\end{array}$ & $\begin{array}{l}1.016^{* * *} \\
(0.084)\end{array}$ & $\begin{array}{l}1.434 * * * \\
(0.087)\end{array}$ \\
\hline Proportion & $0.745^{* * *}$ & $0.867 * * *$ & $0.346^{* *}$ & $0.364 * *$ & $0.696^{* * *}$ \\
\hline Hispanic & $(0.162)$ & $(0.178)$ & $(0.143)$ & $(0.146)$ & $(0.150)$ \\
\hline $\begin{array}{l}\text { Median Income } \\
\text { (Blacks) }\end{array}$ & $\begin{array}{l}0.029 * * * \\
(0.004)\end{array}$ & $\begin{array}{l}0.031 * * * \\
(0.004)\end{array}$ & $\begin{array}{l}0.024 * * * \\
(0.004)\end{array}$ & $\begin{array}{l}0.024 * * * \\
(0.004)\end{array}$ & $\begin{array}{l}0.017 * * * \\
(0.004)\end{array}$ \\
\hline $\begin{array}{l}\text { Median Income } \\
\text { (Hispanics) }\end{array}$ & $\begin{array}{l}0.013 * * * \\
(0.004)\end{array}$ & $\begin{array}{l}0.013 * * * \\
(0.004)\end{array}$ & $\begin{array}{l}0.011 * * * \\
(0.004)\end{array}$ & $\begin{array}{l}0.011 * * * \\
(0.004)\end{array}$ & $\begin{array}{l}0.004 \\
(0.004)\end{array}$ \\
\hline $\begin{array}{l}\text { Median Income } \\
\text { (All) }\end{array}$ & $\begin{array}{l}0.008 \\
(0.007)\end{array}$ & $\begin{array}{l}-0.002 \\
(0.011)\end{array}$ & $\begin{array}{l}-0.056^{* * *} \\
(0.012)\end{array}$ & $\begin{array}{l}-0.056^{* * * *} \\
(0.013)\end{array}$ & $\begin{array}{l}-0.032 * * * \\
(0.012)\end{array}$ \\
\hline $\begin{array}{l}\text { Seniors } \\
\text { (Proportion age } \\
65+\text { ) }\end{array}$ & & $\begin{array}{l}1.316^{* * *} \\
(0.260)\end{array}$ & $\begin{array}{l}1.052 * * * \\
(0.260)\end{array}$ & $\begin{array}{l}1.069 * * * \\
(0.264)\end{array}$ & $\begin{array}{l}0.810 * * * \\
(0.232)\end{array}$ \\
\hline $\begin{array}{l}\text { Military } \\
\text { Employment }\end{array}$ & & $\begin{array}{l}3.790 * * * \\
(0.602)\end{array}$ & $\begin{array}{l}3.705 * * * * \\
(0.656)\end{array}$ & $\begin{array}{l}3.734 * * * * \\
(0.661)\end{array}$ & $\begin{array}{l}1.293 \\
(0.858)\end{array}$ \\
\hline $\begin{array}{l}\text { College } \\
\text { Enrollment }\end{array}$ & & $\begin{array}{l}0.111 \\
(0.303)\end{array}$ & $\begin{array}{l}0.080 \\
(0.300)\end{array}$ & $\begin{array}{l}0.091 \\
(0.303)\end{array}$ & $\begin{array}{l}0.246 \\
(0.259)\end{array}$ \\
\hline $\begin{array}{l}\text { High School } \\
\text { Graduates }\end{array}$ & & $\begin{array}{l}0.040 \\
(0.458)\end{array}$ & $\begin{array}{l}1.520 * * * \\
(0.402)\end{array}$ & $\begin{array}{l}1.561 * * * \\
(0.405)\end{array}$ & $\begin{array}{l}1.623 * * * \\
(0.335)\end{array}$ \\
\hline College Graduates & & $\begin{array}{l}0.818^{* * *} \\
(0.284)\end{array}$ & $\begin{array}{l}1.682 * * * \\
(0.242)\end{array}$ & $\begin{array}{l}1.708 * * * \\
(0.245)\end{array}$ & $\begin{array}{l}1.792 * * * \\
(0.230)\end{array}$ \\
\hline $\begin{array}{l}\text { Unemployment } \\
\text { Rate }\end{array}$ & & $\begin{array}{l}1.833 * * * \\
(0.449)\end{array}$ & $\begin{array}{l}0.831^{*} \\
(0.464)\end{array}$ & $\begin{array}{l}0.881^{*} \\
(0.467)\end{array}$ & $\begin{array}{l}0.459 \\
(0.388)\end{array}$ \\
\hline Number ISPs & & & & & $\begin{array}{l}-0.036^{* * *} \\
(0.005)\end{array}$ \\
\hline
\end{tabular}


Rural (RUCA

$0.024 * * *$

score)

(0.004)

Foreclosure Risk

$-0.743 * * *$

Score

Quarter Fixed Y

Effects

State Fixed Effects

Company Fixed

Effects

Observations

7863

0.187

Y

Y

Y

Y

Y

$\begin{array}{ll}Y & Y \\ Y & Y\end{array}$

R-squared

7863
0.213

7863

7863

7580

Notes: The dependent variable is the log of total number of mortgage complaints over number of households with a mortgage (as reported by the 2007-2011 American Community Survey Estimates) for ZCTAs with at least one complaint. Dummies are included in all regressions for whether the income data for Blacks and Hispanics were available. Standard errors are clustered by state and company. "In progress" responses, companies with less than 1 observations, and complaints lacking a state were excluded. ISP, RUA score, and foreclosure risk score are averaged at the ZCTA level. * denotes significance at the $10 \%$ level, ** denotes significance at the 5\% level, and $* * *$ denotes significance at the $1 \%$ level. 
TABLE 7: LOGIT REGRESSIONS OF UNTIMELY RESPONSES ON ZIP CODE DEMOGRAPHIC FACTORS

\begin{tabular}{|c|c|c|c|c|c|}
\hline & (1) & (2) & (3) & (4) & (5) \\
\hline Proportion Black & $\begin{array}{l}0.006 \\
(0.172)\end{array}$ & $\begin{array}{l}0.045 \\
(0.204)\end{array}$ & $\begin{array}{l}0.047 \\
(0.143)\end{array}$ & $\begin{array}{l}0.046 \\
(0.142)\end{array}$ & $\begin{array}{l}0.149 \\
(0.169)\end{array}$ \\
\hline Proportion & -0.042 & 0.055 & 0.194 & 0.279 & 0.236 \\
\hline Hispanic & $(0.331)$ & $(0.288)$ & $(0.161)$ & $(0.178)$ & $(0.188)$ \\
\hline $\begin{array}{l}\text { Median Income } \\
\text { (Blacks) }\end{array}$ & $\begin{array}{l}0.011 \\
(0.012)\end{array}$ & $\begin{array}{l}0.009 \\
(0.012)\end{array}$ & $\begin{array}{l}0.009 \\
(0.010)\end{array}$ & $\begin{array}{l}0.006 \\
(0.010)\end{array}$ & $\begin{array}{l}0.003 \\
(0.010)\end{array}$ \\
\hline $\begin{array}{l}\text { Median Income } \\
\text { (Hispanics) }\end{array}$ & $\begin{array}{l}0.002 \\
(0.011)\end{array}$ & $\begin{array}{l}0.000 \\
(0.011)\end{array}$ & $\begin{array}{l}-0.000 \\
(0.011)\end{array}$ & $\begin{array}{l}-0.001 \\
(0.012)\end{array}$ & $\begin{array}{l}-0.000 \\
(0.012)\end{array}$ \\
\hline $\begin{array}{l}\text { Median Income } \\
\text { (A11) }\end{array}$ & $\begin{array}{l}-0.011 \\
(0.017)\end{array}$ & $\begin{array}{l}0.003 \\
(0.023)\end{array}$ & $\begin{array}{l}0.008 \\
(0.018)\end{array}$ & $\begin{array}{l}0.019 \\
(0.019)\end{array}$ & $\begin{array}{l}0.028 \\
(0.021)\end{array}$ \\
\hline $\begin{array}{l}\text { Seniors } \\
\text { (Proportion age } \\
65+\text { ) }\end{array}$ & & $\begin{array}{l}0.476 \\
(0.888)\end{array}$ & $\begin{array}{l}0.565 \\
(0.452)\end{array}$ & $\begin{array}{l}0.636 \\
(0.430)\end{array}$ & $\begin{array}{l}0.580 \\
(0.443)\end{array}$ \\
\hline $\begin{array}{l}\text { Military } \\
\text { Employment }\end{array}$ & & $\begin{array}{l}0.211 \\
(0.818)\end{array}$ & $\begin{array}{l}0.390 \\
(0.739)\end{array}$ & $\begin{array}{l}0.012 \\
(0.852)\end{array}$ & $\begin{array}{l}-0.701 \\
(1.149)\end{array}$ \\
\hline $\begin{array}{l}\text { College } \\
\text { Enrollment }\end{array}$ & & $\begin{array}{l}1.265^{* *} \\
(0.582)\end{array}$ & $\begin{array}{l}1.333 * * * \\
(0.409)\end{array}$ & $\begin{array}{l}1.037 * * \\
(0.428)\end{array}$ & $\begin{array}{l}1.028 * * \\
(0.462)\end{array}$ \\
\hline $\begin{array}{l}\text { High School } \\
\text { Graduates }\end{array}$ & & $\begin{array}{l}1.202 \\
(1.640)\end{array}$ & $\begin{array}{l}1.532 * * \\
(0.703)\end{array}$ & $\begin{array}{l}1.416^{* *} \\
(0.714)\end{array}$ & $\begin{array}{l}1.374^{*} \\
(0.753)\end{array}$ \\
\hline $\begin{array}{l}\text { College } \\
\text { Graduates }\end{array}$ & & $\begin{array}{l}0.085 \\
(0.717)\end{array}$ & $\begin{array}{l}0.366 \\
(0.409)\end{array}$ & $\begin{array}{l}0.313 \\
(0.422)\end{array}$ & $\begin{array}{l}-0.017 \\
(0.488)\end{array}$ \\
\hline $\begin{array}{l}\text { Unemployment } \\
\text { Rate }\end{array}$ & & $\begin{array}{l}-0.901 \\
(1.233)\end{array}$ & $\begin{array}{l}-0.647 \\
(0.916)\end{array}$ & $\begin{array}{l}-0.217 \\
(0.951)\end{array}$ & $\begin{array}{l}-0.597 \\
(1.028)\end{array}$ \\
\hline
\end{tabular}




\begin{tabular}{|c|c|c|c|c|c|}
\hline \multicolumn{5}{|l|}{ Number ISPs } & $\begin{array}{l}0.013 \\
(0.009)\end{array}$ \\
\hline $\begin{array}{l}\text { Rural (RUCA } \\
\text { score) }\end{array}$ & & & & & $\begin{array}{l}0.005 \\
(0.015)\end{array}$ \\
\hline Foreclosure Risk & & & & & -0.134 \\
\hline Score & & & & & $(0.150)$ \\
\hline \multicolumn{6}{|l|}{ PRODUCT } \\
\hline $\begin{array}{l}\text { Bank account or } \\
\text { service }\end{array}$ & $\begin{array}{l}-0.595^{* * * *} \\
(0.139)\end{array}$ & $\begin{array}{l}-0.596^{* * * *} \\
(0.137)\end{array}$ & $\begin{array}{l}-0.583 * * * * \\
(0.136)\end{array}$ & $\begin{array}{l}-0.483^{* * * *} \\
(0.109)\end{array}$ & $\begin{array}{l}-0.526^{* * * *} \\
(0.117)\end{array}$ \\
\hline Consumer loan & $\begin{array}{l}-0.326^{*} \\
(0.197)\end{array}$ & $\begin{array}{l}-0.330^{*} \\
(0.196)\end{array}$ & $\begin{array}{l}-0.322 * \\
(0.191)\end{array}$ & $\begin{array}{l}0.262 \\
(0.231)\end{array}$ & $\begin{array}{l}0.280 \\
(0.233)\end{array}$ \\
\hline Credit card & $\begin{array}{l}-0.718^{* * * *} \\
(0.143)\end{array}$ & $\begin{array}{l}-0.722^{* * * *} \\
(0.142)\end{array}$ & $\begin{array}{l}-0.709 * * * \\
(0.134)\end{array}$ & $\begin{array}{l}-0.303 * * \\
(0.144)\end{array}$ & $\begin{array}{l}-0.345^{* * *} \\
(0.152)\end{array}$ \\
\hline Credit reporting & $\begin{array}{l}-2.977^{* * * *} \\
(0.563)\end{array}$ & $\begin{array}{l}-2.976^{* * * *} \\
(0.563)\end{array}$ & $\begin{array}{l}-2.985^{* * * *} \\
(0.561)\end{array}$ & $\begin{array}{l}0.376 \\
(0.757)\end{array}$ & $\begin{array}{l}0.502 \\
(0.768)\end{array}$ \\
\hline Student loan & $\begin{array}{l}-1.565^{\text {***; }} \\
(0.278)\end{array}$ & $\begin{array}{l}-1.575^{* * * *} \\
(0.277)\end{array}$ & $\begin{array}{l}-1.575 * * * \\
(0.273)\end{array}$ & $\begin{array}{l}-0.058 \\
(0.220)\end{array}$ & $\begin{array}{l}-0.095 \\
(0.231)\end{array}$ \\
\hline $\begin{array}{l}\text { Product/Issue } \\
\text { Interactions }\end{array}$ & Y & $\mathrm{Y}$ & $\mathrm{Y}$ & $\mathrm{Y}$ & $\mathrm{Y}$ \\
\hline $\begin{array}{l}\text { Quarter Fixed } \\
\text { Effects }\end{array}$ & $\mathrm{Y}$ & $\mathrm{Y}$ & $\mathrm{Y}$ & $\mathrm{Y}$ & $\mathrm{Y}$ \\
\hline $\begin{array}{l}\text { State Fixed } \\
\text { Effects }\end{array}$ & & & $\mathrm{Y}$ & $\mathrm{Y}$ & $\mathrm{Y}$ \\
\hline $\begin{array}{l}\text { Company Fixed } \\
\text { Effects }\end{array}$ & & & & $\mathrm{Y}$ & $\mathrm{Y}$ \\
\hline Observations & 107270 & 107270 & 107270 & 95680 & 91719 \\
\hline
\end{tabular}

Notes: The dependent variable is a 0-1 dummy for whether a complaint was resolved in an untimely fashion. Standard errors are clustered by state and company. As some ZIP codes have no Black or Hispanic residents, dummies are included in all regressions for whether income 
data for blacks and Hispanics were available. "In progress" responses, companies with less than 10 observations dropped, and complaints lacking a state were excluded. For the product and issue fixed effects, mortgages were the omitted product. See Table 9 for analysis of the issue fixed effects. Significance levels are denoted by $*$ for the $10 \%$ level, ${ }^{* *}$ for $5 \%$ level, and $* * *$ for the $1 \%$ level. 
TABLE 8: LOGIT REGRESSIONS OF DISPUTED RESPONSES ON ZIP CODE DEMOGRAPHIC FACTORS

\begin{tabular}{|c|c|c|c|c|c|}
\hline & (1) & (2) & (3) & (4) & (5) \\
\hline Proportion Black & $\begin{array}{l}-0.140 * * * \\
(0.043)\end{array}$ & $\begin{array}{l}-0.078 \\
(0.047)\end{array}$ & $\begin{array}{l}-0.055 \\
(0.056)\end{array}$ & $\begin{array}{l}-0.068 \\
(0.056)\end{array}$ & $\begin{array}{l}-0.017 \\
(0.066)\end{array}$ \\
\hline Proportion & $-0.125^{* *}$ & -0.055 & -0.056 & -0.070 & -0.062 \\
\hline Hispanic & $(0.055)$ & $(0.063)$ & $(0.070)$ & $(0.071)$ & $(0.074)$ \\
\hline $\begin{array}{l}\text { Median Income } \\
\text { (Blacks) }\end{array}$ & $\begin{array}{l}-0.002 \\
(0.004)\end{array}$ & $\begin{array}{l}0.000 \\
(0.004)\end{array}$ & $\begin{array}{l}-0.001 \\
(0.004)\end{array}$ & $\begin{array}{l}-0.001 \\
(0.004)\end{array}$ & $\begin{array}{l}-0.001 \\
(0.004)\end{array}$ \\
\hline $\begin{array}{l}\text { Median Income } \\
\text { (Hispanics) }\end{array}$ & $\begin{array}{l}0.005 \\
(0.004)\end{array}$ & $\begin{array}{l}0.005 \\
(0.004)\end{array}$ & $\begin{array}{l}0.004 \\
(0.004)\end{array}$ & $\begin{array}{l}0.004 \\
(0.004)\end{array}$ & $\begin{array}{l}0.005 \\
(0.004)\end{array}$ \\
\hline $\begin{array}{l}\text { Median Income } \\
\text { (A11) }\end{array}$ & $\begin{array}{l}0.014 * * \\
(0.006)\end{array}$ & $\begin{array}{l}-0.001 \\
(0.007)\end{array}$ & $\begin{array}{l}-0.004 \\
(0.008)\end{array}$ & $\begin{array}{l}-0.005 \\
(0.008)\end{array}$ & $\begin{array}{l}-0.001 \\
(0.008)\end{array}$ \\
\hline $\begin{array}{l}\text { Seniors } \\
\text { (Proportion age } \\
65+\text { ) }\end{array}$ & & $\begin{array}{l}0.463 * * * \\
(0.166)\end{array}$ & $\begin{array}{l}0.787 * * * \\
(0.191)\end{array}$ & $\begin{array}{l}0.773 * * * \\
(0.191)\end{array}$ & $\begin{array}{l}0.690 * * * \\
(0.209)\end{array}$ \\
\hline $\begin{array}{l}\text { Military } \\
\text { Employment }\end{array}$ & & $\begin{array}{l}0.259 \\
(0.256)\end{array}$ & $\begin{array}{l}0.225 \\
(0.269)\end{array}$ & $\begin{array}{l}0.191 \\
(0.268)\end{array}$ & $\begin{array}{l}0.714^{*} \\
(0.395)\end{array}$ \\
\hline $\begin{array}{l}\text { College } \\
\text { Enrollment }\end{array}$ & & $\begin{array}{l}-0.302 \\
(0.197)\end{array}$ & $\begin{array}{l}-0.184 \\
(0.215)\end{array}$ & $\begin{array}{l}-0.180 \\
(0.215)\end{array}$ & $\begin{array}{l}-0.163 \\
(0.223)\end{array}$ \\
\hline $\begin{array}{l}\text { High School } \\
\text { Graduates }\end{array}$ & & $\begin{array}{l}-0.439 \\
(0.325)\end{array}$ & $\begin{array}{l}0.196 \\
(0.356)\end{array}$ & $\begin{array}{l}0.203 \\
(0.359)\end{array}$ & $\begin{array}{l}0.101 \\
(0.377)\end{array}$ \\
\hline $\begin{array}{l}\text { College } \\
\text { Graduates }\end{array}$ & & $\begin{array}{l}0.254 \\
(0.181)\end{array}$ & $\begin{array}{l}0.569 * * * \\
(0.197)\end{array}$ & $\begin{array}{l}0.557^{* * * *} \\
(0.198)\end{array}$ & $\begin{array}{l}0.449 * * \\
(0.228)\end{array}$ \\
\hline $\begin{array}{l}\text { Unemployment } \\
\text { Rate }\end{array}$ & & $\begin{array}{l}0.064 \\
(0.299)\end{array}$ & $\begin{array}{l}0.150 \\
(0.354)\end{array}$ & $\begin{array}{l}0.180 \\
(0.358)\end{array}$ & $\begin{array}{l}0.223 \\
(0.383)\end{array}$ \\
\hline Number ISPs & & & & & 0.005 \\
\hline
\end{tabular}




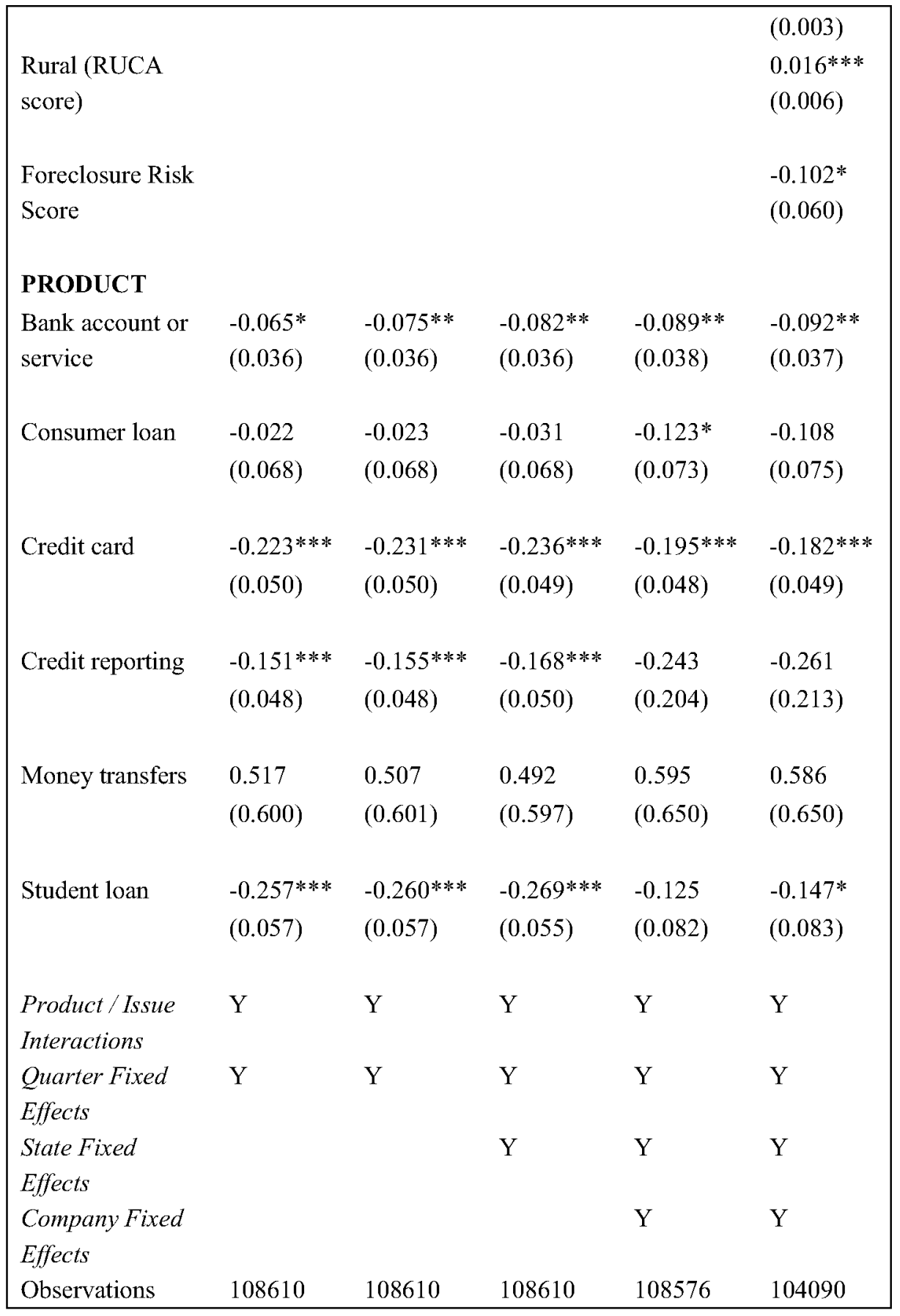

Notes: The dependent variable is a 0-1 dummy variable for whether an individual complaint response was disputed. Standard errors clustered 
by state and company. As some ZIP codes have no Black or Hispanic residents, dummies are included in all regressions for whether income data for blacks and Hispanics were available. "In progress" responses, companies with less than 10 observations, and complaints without a state were excluded. For the product- and issue-fixed effects, mortgages were the omitted product. See Table 10 for analysis of the issue fixed effects. Significance levels are denoted by $*$ for significance at the $10 \%$ level, $* *$ for significance at the $5 \%$ level, and $* * *$ for significance at the $1 \%$ level. 
TABLe 9: Product By ISSUe InTERactions from TABLe 7: The Five Product Issues Most AND Least LiKely to Be UnTIMely

\begin{tabular}{|c|c|c|}
\hline PRODUCT: ISSUE & $\begin{array}{l}\text { Predicted } \\
\text { Probability of } \\
\text { Being } \\
\text { Untimely }\end{array}$ & $\begin{array}{l}\text { Coefficient } \\
\text { from } \\
\text { Specification in } \\
\text { Table } 7\end{array}$ \\
\hline \multicolumn{3}{|l|}{ Least Likely to be Untimely } \\
\hline Credit card: Payoff process & 0.006 & $\begin{array}{l}-1.397 * * \\
(0.578)\end{array}$ \\
\hline $\begin{array}{l}\text { Credit reporting: Credit reporting } \\
\text { company's investigation }\end{array}$ & 0.006 & $\begin{array}{l}1.592 \\
(1.101)\end{array}$ \\
\hline $\begin{array}{l}\text { Consumer loan: Taking out the loan } \\
\text { or lease }\end{array}$ & 0.009 & $\begin{array}{l}-1.540^{*} \\
(0.792)\end{array}$ \\
\hline Credit card: APR or interest rate & 0.012 & $\begin{array}{l}-0.550^{* *} \\
(0.239)\end{array}$ \\
\hline Credit card: Credit determination & 0.014 & $\begin{array}{l}-0.424 \\
(0.406)\end{array}$ \\
\hline \multicolumn{3}{|l|}{ Most Likely to be Untimely } \\
\hline $\begin{array}{l}\text { Credit reporting: Improper use of } \\
\text { my credit report }\end{array}$ & 0.042 & $\begin{array}{l}0.954 \\
(1.312)\end{array}$ \\
\hline $\begin{array}{l}\text { Credit card: Identity theft / Fraud / } \\
\text { Embezzlement }\end{array}$ & 0.044 & $\begin{array}{l}0.625^{* * *} \\
(0.197)\end{array}$ \\
\hline Credit card: Arbitration & 0.048 & $\begin{array}{l}0.862 \\
(0.867)\end{array}$ \\
\hline Credit card: Sale of account & 0.067 & $\begin{array}{l}1.064^{*} \\
(0.608)\end{array}$ \\
\hline $\begin{array}{l}\text { Consumer loan: Shopping for a line } \\
\text { of credit }\end{array}$ & 0.071 & $\begin{array}{l}0.620 \\
(0.610)\end{array}$ \\
\hline
\end{tabular}


Notes: This table reports additional coefficients from Table 7, Column (5). The first column here lists the product and issue, the second column shows the predicted probability of that issue being untimely from the specification in the final column of Table 7 , and the third column shows the coefficient from the specification used in the final column of Table 7. The product/issue effects shown are those from Table 7 with the five highest and lowest predicted probabilities of being untimely. For the issues within each product, the analysis was conducted relative to the most numerous type of issue for each product: these were (i) bank account: account opening, closing, or management; (ii) consumer loan: managing the loan or lease; (iii) credit reporting: incorrect information on credit report; (iv) credit card: APR or interest rate; (v) money transfer: other transaction issues; (vi) mortgage: loan modification, collection, or foreclosure; (vii) student loan: repaying your loan. Significance levels are denoted by ${ }^{*}$ for significance at the $10 \%$ level, $* *$ for significance at the $5 \%$ level, and $* * *$ for significance at the $1 \%$ level. 
Table 10: Product by ISSUe INTERactions From Table 8: The Five Product IsSues Most AND LeAst LIKELY to BE DISPUTED

\begin{tabular}{|c|c|c|}
\hline PRODUCT: ISSUE & $\begin{array}{l}\text { Predicted } \\
\text { Probability of } \\
\text { Being Disputed }\end{array}$ & $\begin{array}{l}\text { Coefficient } \\
\text { from Table } 8\end{array}$ \\
\hline \multicolumn{3}{|l|}{ Least Likely to be Disputed } \\
\hline Credit card: Late fee & 0.115 & $\begin{array}{l}-0.623^{* * *} \\
(0.108)\end{array}$ \\
\hline $\begin{array}{l}\text { Credit reporting: Credit monitoring } \\
\text { or identity protection }\end{array}$ & 0.131 & $\begin{array}{l}-0.380^{*} \\
(0.204)\end{array}$ \\
\hline Credit card: Cash advance fee & 0.132 & $\begin{array}{l}-0.582 \\
(0.395)\end{array}$ \\
\hline Credit card: Other fee & 0.132 & $\begin{array}{l}-0.514 * * * \\
(0.154)\end{array}$ \\
\hline $\begin{array}{l}\text { Credit card: Application processing } \\
\text { delay }\end{array}$ & 0.134 & $\begin{array}{l}-0.437 \\
(0.274)\end{array}$ \\
\hline \multicolumn{3}{|l|}{ Most Likely to be Disputed } \\
\hline $\begin{array}{l}\text { Consumer loan: Taking out the } \\
\text { loan or lease }\end{array}$ & 0.261 & $\begin{array}{l}0.192 \\
(0.152)\end{array}$ \\
\hline Credit card: Arbitration & 0.261 & $\begin{array}{l}0.364 \\
(0.284)\end{array}$ \\
\hline Credit card: Bankruptcy & 0.302 & $\begin{array}{l}0.579^{* * *} \\
(0.217)\end{array}$ \\
\hline Credit card: Convenience checks & 0.303 & $\begin{array}{l}0.509 \\
(0.393)\end{array}$ \\
\hline Credit card: Cash advance & 0.328 & $\begin{array}{l}0.723 * * * \\
(0.270)\end{array}$ \\
\hline
\end{tabular}


Notes: This table reports additional coefficients from Table 8, Column (5). The first column here lists the product and issue, the second column shows the predicted probability of that issue being disputed from the specification in the final column of Table 8 , and the third column shows the coefficient from the specification used in the final column of Table 8. The product/issue effects shown are those from Table 8 with the five highest and lowest predicted probabilities of being disputed. For the issues with each product, the following (most numerous type of issue for each product) are omitted: (i) Bank account, Account opening, closing, or management; (ii) Consumer loan: Managing the loan or lease; (iii) Credit Reporting: Incorrect information on credit report; (iv) Credit card: APR or interest rate; (v) Money transfer: Other transaction issues; (vi) Mortgage: Loan modification, collection, foreclosure; (vii) Student loan: Repaying your loan. Significance levels are denoted by * for significance at the $10 \%$ level, $* *$ for significance at the $5 \%$ level, and $* * *$ for significance at the $1 \%$ level. 
Notes \& Observations 